\title{
Distribution of Bacterial Populations in a Stratified Fjord (Mariager Fjord, Denmark) Quantified by In Situ Hybridization and Related to Chemical Gradients in the Water Column
}

\author{
NIELS B. RAMSING,${ }^{1 *}$ HENRIK FOSSING,${ }^{1}$ TIMOTHY G. FERDELMAN, ${ }^{1}$ \\ FINN ANDERSEN, ${ }^{2}$ AND BO THAMDRUP ${ }^{1}$ \\ Max Planck Institute for Marine Microbiology, Bremen, Germany, ${ }^{1}$ \\ and Nordjyllands Amt, Aalborg, Denmark ${ }^{2}$
}

Received 28 August 1995/Accepted 29 January 1996

\begin{abstract}
The vertical distribution of major and intermediate electron acceptors and donors was measured in a shallow stratified fjord. Peaks of zero valence sulfur, Mn(IV), and Fe(III) were observed in the chemocline separating oxic surface waters from sulfidic and anoxic bottom waters. The vertical fluxes of electron acceptors and donors (principally $\mathrm{O}_{2}$ and $\mathrm{H}_{2} \mathrm{~S}$ ) balanced within 5\%; however, the zones of oxygen reduction and sulfide oxidation were clearly separated. The pathway of electron transfer between $\mathrm{O}_{2}$ and $\mathrm{H}_{2} \mathrm{~S}$ was not apparent from the distribution of sulfur, nitrogen, or metal compounds investigated. The chemical zonation was related to bacterial populations as detected by ethidium bromide (EtBr) staining and by in situ hybridization with fluorescent oligonucleotide probes of increasing specificity. About half of all EtBr-stained cells were detectable with a general oligonucleotide probe for all eubacteria when digital image analysis algorithms were used to improve sensitivity. Both EtBr staining and hybridization indicated a surprisingly uniform distribution of bacteria throughout the water column. However, the average cell size and staining intensity as well as the abundance of different morphotypes changed markedly within the chemocline. The constant overall cell counts thus concealed pronounced population shifts within the water column. Cells stained with a delta 385 probe (presumably sulfate-reducing bacteria) were detected at the chemocline at about $5 \times 10^{4}$ cells per ml, and this concentration increased to $2 \times 10^{5}$ cells per $\mathrm{ml}$ beneath the chemocline. A long slim rod-shaped bacterium was found in large numbers in the oxic part of the chemocline, whereas large ellipsoid cells dominated at greater depth. Application of selective probes for known genera of sulfate-reducing bacteria gave only low cell counts, and thus it was not possible to identify the dominant morphotypes of the sulfate-reducing community.
\end{abstract}

The vertical zonation of electron donors and electron acceptors in chemically stratified marine water columns resembles the distribution observed in marine sediments and microbial mats. This gradient system is the basis for (and possibly the result of) a pronounced stratification of the associated microbial populations. A main difference between the systems is the spatial scale involved; the scales of the two systems differ by at least 3 orders of magnitude. Principal changes in basic metabolism that occur over a few millimeters in coastal sediments are extended to several meters in stratified water columns, which greatly facilitates accurate and detailed sampling. An additional convenience when fluorescent stains are applied is the virtual absence of mineral grains and refractive detrital matter known to generate problems with autofluorescence and unspecific staining in sediment samples. The bacterial populations and the concurrent chemical environments of many permanently stratified marine water bodies have been investigated by traditional cultivation-dependent methods (e.g., the Black Sea [52] Framvaren [60, 61], Gotland Deep [4], and the Cariaco Trench [53]). However, it has been estimated that the culturability of marine bacteria is presently less than $0.1 \%(18,37$, 38 ). It is thus not surprising that the application of novel, cultivation-independent methods for studies of free-living marine bacteria or marine bacteria attached to aggregates $(10,11$,

\footnotetext{
* Corresponding author. Present address: Department of Microbial Ecology, Institute of Biological Sciences, Building 540, Aarhus University, Ny Munkegade, DK-8000 Aarhus C, Denmark.
}

24, 25) has revealed large numbers of unknown organisms which appear to be largely unaffiliated with previous isolates from the same environments. To our knowledge, stratified water columns have never been investigated by these methods; yet, such ecosystems appear ideally suited for a cross evaluation of the novel techniques and culture-based approaches and biogeochemical data.

Mariager Fjord is a long shallow Danish threshold fjord with a strong redox stratification of the water column (47). A map and transect of Mariager Fjord are shown in Fig. 1A to C. The central part of the fjord, north of the town of Mariager, is a basin with a depth of around $26 \mathrm{~m}$. The long $(>20-\mathrm{km})$, narrow $(<2-\mathrm{km})$ inlet to the fjord is less than $10 \mathrm{~m}$ deep, so influxes of cold, dense, oxygenated water from the open sea to the basin are rare events that are not observed every year (Fig. 1D) (47). Mariager Fjord has been the subject of two investigations (15, 32); however, a characterization of the bacterial communities and their concurrent chemical environment has never been made.

The purpose of the study reported here was to cross correlate data obtained by in situ hybridization by using fluorescently labelled oligonucleotide probes with data from a thorough characterization of the chemical environment and with rate estimates for the dominant processes. We concentrated on the role of sulfate-reducing bacteria in view of recent accounts of sulfate reduction in the presence of $\mathrm{O}_{2}$ in both microbial mats $(5,22,34)$ and marine sediments $(35)$ and even within a water column (30). Results from this study are also compared 

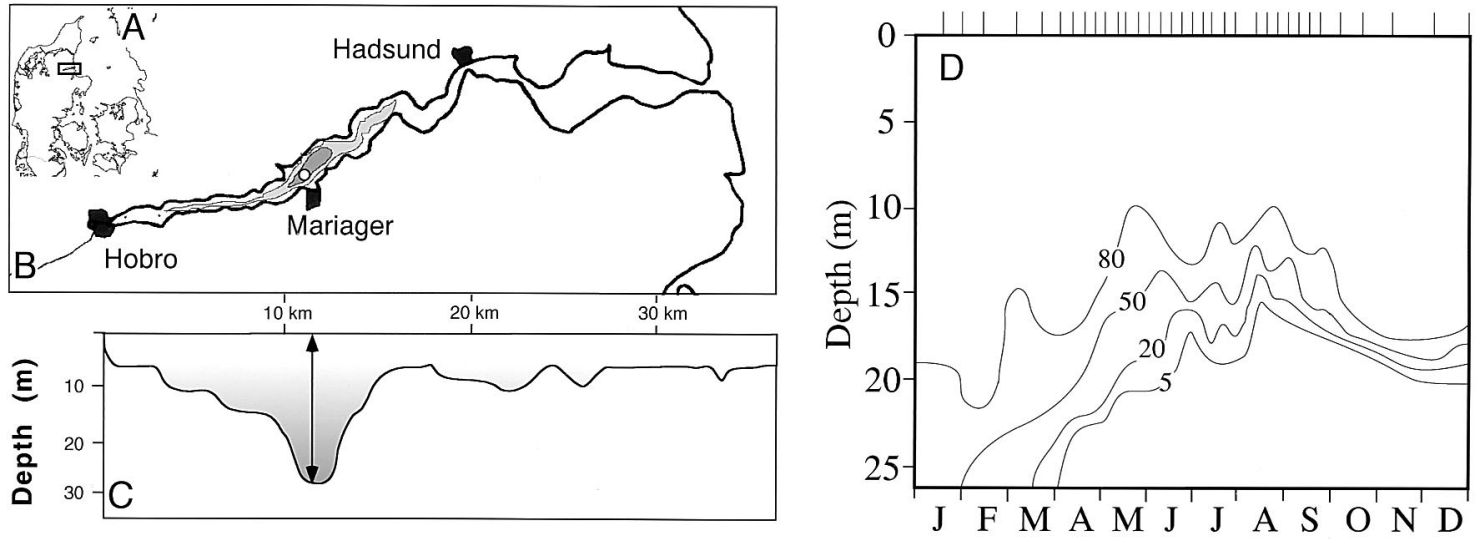

FIG. 1. (A) Map of Denmark. The location of Mariager Fjord is indicated by the box. (B) Map of Mariager Fjord. Depth is indicated by shading (10 and $20 \mathrm{~m}$ depth curves). The sampling site is marked by a white circle. (C) Transect through Mariager Fjord. The sampling site is indicated by a double arrow. (D) Isopleth of oxygen concentration (micromolar) at the sampling site throughout the year 1993. Sampling dates are indicated by thin vertical lines above the graph.

with the results of most-probable-number cultivations and analysis of extractable nucleic acids presented in an accompanying paper (65) in order to illuminate the advantages and disadvantages of the different molecular and traditional methods for enumerating bacterial populations.

\section{MATERIALS AND METHODS}

Water sampling. Water samples were collected from Station M3 $\left(56^{\circ} 39^{\prime} 66^{\prime \prime} \mathrm{N}\right.$, $9^{\circ} 58^{\prime} 56^{\prime \prime} \mathrm{E}$ ) on 19 and 20 August 1993 in the flat interior basin, which has a depth of $24.3 \mathrm{~m}$ (Fig. 1B). Water from selected depths was sampled by lowering a pump from the research vessel (R/V Genetica II; Aarhus University, Aarhus, Denmark). Vertical sampling accuracy was better than $20 \mathrm{~cm}$, as any wave-induced motion of the vessel was negligible. Attached to the frame carrying the pump was a calibrated conductivity-temperature-depth sensor (ECO-probe; Meerestechnik Elektronik GmbH, Trappenkamp, Germany) measuring pressure, temperature, conductivity, oxygen (two independent sensors), incident light, and fluorescence. The conductivity-temperature-depth sensor was deployed before, during, and after water sampling. The stability and reproducibility of the sampling were shown by virtually identical conductivity-temperature-depth profiles obtained throughout the 24-h sampling period (data not shown). Water salinity, density, and depth were calculated from temperature, conductivity, and pressure according to guidelines from the United Nations Educational, Scientific, and Cultural Organization $(48,68)$.

Oxygen and sulfide analysis. Oxygen concentrations were measured by Winkler titration (26) within an $\mathrm{N}_{2}$-filled glove bag to avoid contamination with atmospheric oxygen. Sulfide was measured colorimetrically by the methylene blue technique (7)

Sulfur speciation. Zero valence elemental sulfur was measured as $S_{8}$ by highpressure liquid chromatography (HPLC) after the preservation of the water in a zinc solution. Briefly, $2 \mathrm{ml}$ of water was injected without exposure to air into 1.0 $\mathrm{ml}$ of a $1 \%(\mathrm{wt} / \mathrm{vol}) \mathrm{ZnCl}_{2}$ solution. Of this suspension, $0.10 \mathrm{ml}$ was pipetted into $1.0 \mathrm{ml}$ of HPLC-grade methanol. Cyclooctasulfur dissolved in the methanol was measured under the following HPLC conditions: column, Zorbax-ODS (120 by $4 \mathrm{~mm}$; 60-nm particle size; Knauer, Berlin, Germany); eluant, $100 \%$ methanol; pump, Waters 510 (flow rate, $1 \mathrm{ml} \mathrm{min}^{-1}$; Waters, Milford, Mass.); detector, Waters $440 \mathrm{UV}(254 \mathrm{~nm})$. Cyclooctasulfur eluted at $4.1 \mathrm{~min}$ under these conditions.

Tetrathionate and thiosulfate were measured by anion chromatography by following the method of Bak et al. (2), with an LCA-A08 120-by-6-mm column (Sykam, Gilching, Germany) and an S 1211 pump (Sykam), both having allpolyether-ether-ketone construction, and a Linear $200 \mathrm{UV}$ detector set at 215 nm (Linear Instruments, Fremont, Calif.) being used. Samples were injected onto the column with a Rheodyne 9125 injector (Rheodyne, Cotati, Calif.), which is also constructed of polyether-ether-ketone. Samples were injected by backfilling the injector by using a Teflon cannula attached from the sampling syringe to the exit port of the injector, thus avoiding contact with air or metal syringe needles. The detection limits for tetrathionate and thiosulfate at the time of sampling were estimated to be 1 and $5 \mu \mathrm{M}$, respectively.

Direct rate measurements. Approximately $250 \mathrm{ml}$ of water from different depths $(8,13,14.5,16$, and $20 \mathrm{~m})$ was transferred without air contamination to gastight plastic bags. Sulfate reduction rates were estimated by the addition of ${ }^{35} \mathrm{SO}_{4}{ }^{2-}$ radiotracer $(1.5 \mathrm{ml} ; 2.7 \mathrm{MBq}$; Amersham Buchler, Braunschweig, Germany) (33) followed by up to $24 \mathrm{~h}$ of incubation at the sampling depth. Sulfate reduction was terminated by $1: 1$ (volume) mixing with $20 \%$ (wt/vol) zinc acetate. The production of reduced ${ }^{35} \mathrm{~S}$ (i.e., radioactive $\mathrm{H}_{2} \mathrm{~S}, \mathrm{FeS}, \mathrm{S}^{0}$, and $\mathrm{FeS}_{2}$ ) was measured by hot chromium reduction (20). Oxygen consumption was measured by Winkler titration before and after incubation.

Manganese and iron analysis. Water samples for dissolved and particulate $\mathrm{Mn}$ and $\mathrm{Fe}$ were retrieved without the samples contacting the atmosphere. Fifty milliliters was filtered through $\mathrm{N}_{2}$-flushed fiberglass filters (Whatman $\mathrm{GF} / \mathrm{F}$ ), and a subsample of the filtrate was immediately acidified with $6 \mathrm{~N} \mathrm{HCl}(1 \%$ volume) Manganese and iron oxides on the filters were extracted by dithionite-citrateacetic acid extraction $(43,67)$. Manganese in filtrates and extracts was analyzed by flame atomic absorption spectroscopy. Iron was analyzed spectrophotometrically with Ferrozine (64).

Nitrate and ammonia analysis. The combined concentration of nitrite and nitrate in the water samples was determined by flow injection analysis, in which the nitrate is initially reduced to nitrite in a copper-coated cadmium column and subsequently detected colorimetrically after a reaction with sulfanilamide and $N$-(1-naphthyl)-ethylene diamine (63). Ammonia was quantified by flow injection analysis with gas exchange and conductivity detection (29).

Fixation of samples for in situ hybridization. Fixative was prepared as follows. Paraformaldehyde (4\%; Merck, Darmstadt, Germany) in 1× phosphate-buffered saline (130 mM sodium chloride, $10 \mathrm{mM}$ sodium phosphate buffer [pH 7.2]) and $0.1 \%$ Triton $\mathrm{X}-100$ were heated to $60^{\circ} \mathrm{C}$ with vigorous stirring and subsequent chilling on ice. Freshly prepared fixative $(10 \mathrm{ml})$ was added to a $20-\mathrm{ml}$ water sample, mixed, and stored at $4^{\circ} \mathrm{C}$ for 50 to $60 \mathrm{~h}$ before filtration. An experiment with water samples from Mariager Fjord showed no significant difference in hybridization efficiencies for fixation times ranging from $4 \mathrm{~h}$ to 14 days. Only with storage times of $\geq 1$ month were reduced hybridization efficiency and increased autofluorescence observed.

Filtration and dehydration of samples for in situ hybridization. Special filtration devices made of transparent Perplex which divided a standard circular 25-mm-diameter filter into four round wells each with a diameter of $6 \mathrm{~mm}$ were constructed. The devices were used for the initial filtration and subsequen dehydration; all pretreatments, hybridizations, or stainings; and all subsequent washes. Reagents were pipetted into the wells and incubated for the specified lengths of time, during which surface tension and capillary forces prevented the liquid from draining through. Each well was sealed with a rubber O-ring so that liquid transfer between wells was prevented. Two different amounts of fixed water samples $(200$ and $600 \mu \mathrm{l})$ were applied to the first two wells. The last two wells were used for reference cell mixtures. Aluminum oxide filters $(0.2 \mathrm{~mm}$ pore size; Anopore; Millipore GmbH, Eschborn, Germany) were used. The filtered samples were dehydrated in the filtration devices with increasing concentrations of ethanol, (twice with $200 \mu \mathrm{l}$ of $50 \%$ ethanol, twice with $200 \mu \mathrm{l}$ of $80 \%$ ethanol, and three times with $200 \mu \mathrm{l}$ of $100 \%$ ethanol per well). Excess liquid was removed by gentle suction. The dehydrated filters were removed from the filtration device and stored in a desiccated state at $4{ }^{\circ} \mathrm{C}$. The hybridization efficiency and autofluorescence of the desiccated samples were unaltered for $>3$ months.

Reference cell mixtures. Two mixtures of cells from pure cultures were used to evaluate hybridization efficiency. Mixture A consisted of Saccharomyces cerevisiae (from Dr. Oetker dry yeast packages), Escherichia coli (a kind donation of Lars Kongsbak Poulsen, Danish Technical University, Lyngby, Denmark), De sulfoarculus barsii DSM 2075, Desulfobacter postgatei DSM 2553, and Desulfovibrio gigas DSM 1382. Mixture B contained Desulfovibrio desulfuricans DSM 1926, Desulfobulbus sp. strain DSM 2058, Desulfobacterium vacuolatum DSM 3385, and LTK10, a Desulfobulbus-related strain isolated from a coastal marine sediment (31a). The mixtures were selected to contain representatives of major groups of sulfate-reducing bacteria which could be identified on the basis of morphology so that the hybridization efficiency of selective probes for subgroups of sulfate-reducing bacteria could be evaluated. 
Oligonucleotide probes. The probes are named with a number that indicates the position of the first base in the target sequence (by E. coli numbering) and a subsequent letter that denotes the labelling fluorophore ( $\mathrm{F}$ for fluorescein and $\mathrm{R}$ for tetramethylrhodamine). The following fluorescently labelled oligonucleotide probes were used in this study. (i) $338 \mathrm{~F}$, a general probe for all eubacteria (5'-GCT GCC TCC CGT AGG AGT-3'), and 385R, a probe for delta subdivision sulfate-reducing bacteria (5'-CGG CGT CGC TGC GTC AGG-3'), were used in combination with $35 \%$ formamide in the hybridization solution to achieve a stringent hybridization. (ii) $221 \mathrm{~F}$, a probe for members of the genus Desulfobacterium (5'-TGC GCG GAC TCA TCT TCA AA-3'), and 660R, a probe for members of the genus Desulfobulbus (5'-GAA TTC CAC TTT CCC CTC TG-3'), were used with $25 \%$ formamide. (iii) $129 \mathrm{~F}$, a probe for members of the genus Desulfobacter (5'-CAG GCT TGA AGG CAG ATT-3'), and 687R, a probe for members of the genus Desulfovibrio (5'-TAC GGA TTT CAC TCC T-3'), were used with $15 \%$ formamide. (iv) $814 \mathrm{~F}$, a probe for members of a collection of weakly related genera including Desulfococcus, Desulfosarcina, and Desulfobotulus (5'-ACC TAG TGA TCA ACG TTT-3'), and 804R, a broad probe for members of several sulfate-reducing genera including Desulfobacter, Desulfobacterium, and those of probe 814F (5'-CAA CGT TTA CTG CGT GGA-3'), were used with $10 \%$ formamide. (v) Control-F and Control-R, two nonhybridizing control probes labelled with fluorescein and tetramethylrhodamine, respectively, were used. Their sequence, 5'-CCT GAC GCA GCG ACG CCG-3', was identical to the target sequence of probe 385 (i.e., a forward sequence), and therefore they were used with $35 \%$ formamide. The first set of probes, $338 \mathrm{~F}$ and $385 \mathrm{R}$, was devised by Amann et al. (1), whereas the probes for specific groups of sulfate-reducing bacteria were devised by Devereux et al. (13). All probes were fluorescently labelled and HPLC purified and were purchased from Biometra, Göttingen, Germany.

In situ hybridization. Dehydrated filters were mounted in the filtration device and treated with $200 \mu \mathrm{l}$ of prehybridization solution per well. The solution contained formamide at various percentages (see above), $5 \times$ SSC buffer $(1 \times$ SSC is $0.15 \mathrm{M} \mathrm{NaCl}$ plus $0.015 \mathrm{M}$ sodium citrate $[\mathrm{pH}, \sim 7.0])$ and $0.1 \%$ Triton $\mathrm{X}-100$. After at least $30 \mathrm{~min}$ of incubation, the prehybridization solution was removed and $60 \mu \mathrm{l}$ of hybridization solution containing various percentages of deionized formamide, $5 \times$ SSC, $0.1 \%$ Triton X-100, $0.5 \mathrm{mg}$ of poly(A) per ml, and $10 \times$ Denhardt's solution $(1 \times$ Denhardt's solution is $0.02 \%$ Ficoll, $0.02 \%$ bovine serum albumin, and $0.02 \%$ polyvinylpyrrolidone) was added to each well. All chemicals were purchased from Merck or from Fluka, Deisenhofen, Germany. Hybridization was carried out for $2 \mathrm{~h}$ at $37^{\circ} \mathrm{C}$ in the filtration device (increasing the hybridization time beyond $2 \mathrm{~h}$ had no apparent effect on the outcome). The hybridization solution was removed by suction, and the filters were washed twice with $200 \mu \mathrm{l}$ of prehybridization solution incubated $>10 \mathrm{~min}$ at $37^{\circ} \mathrm{C}$ and then twice with $200 \mu \mathrm{l}$ of $1 \times \mathrm{SSC}$ at room temperature. The filters were mounted in Mowiol ( $\mathrm{pH} \mathrm{8.5;} \mathrm{Hoechst,} \mathrm{Frankfurt,}$ Germany) and stored at $4^{\circ} \mathrm{C}$ until they were evaluated by microscopy.

EtBr staining. Ethidium bromide $(\mathrm{EtBr})(200 \mu \mathrm{l}$ at $3 \mu \mathrm{g} / \mathrm{ml})$ in filtered seawater was applied to each well of the filtration device. After a 10-min incubation at room temperature, the liquid was removed by gentle suction. The filters were mounted in Mowiol.

Image acquisition and processing. The slides were examined with a Zeiss Axioplan epifluorescence microscope (Carl Zeiss, Oberkochen, Germany) with Zeiss standard filters (filterset 10, blue excitation and green emission [selectively for fluorescein]; filterset 15 , green excitation and red emission [for rhodamine and $\mathrm{EtBr}])$. The pictures presented were taken with a $63 \times$ plan-NEOFLUAR oil immersion objective without additional magnification.

The microscope was equipped with a Peltier cooled slow-scan charge-coupled device camera (Photometrics, Tucson, Ariz.) with a Metachrome II extended UV charge-coupled device chip (KAF $1400 ; 1,320$ by 1,035 pixels; transfer rate, 500 $\mathrm{kHz}$; pixel size, 6.8 by $6.8 \mu \mathrm{m}$ ). The camera was controlled by a Quadra 700 computer (Apple) with a Photometrics charge-coupled device camera controller. Digital pictures were acquired as 12-bit images with the NU 200 program (Photometrics). The digital pictures were imported as intensity-calibrated, 8-bit TIFF files into the NIH Image program, version 1.57, for quantitative analysis (see below). NIH Image was written by Wayne Rasband, National Institutes of Health, Bethesda, Md. The program is freely available from the anonymous FTP site (zippy.nimh.nih.gov) on the Internet.

Digital image analysis. Cells were demarcated with a modified Marr-Hildreth detection algorithm similar to the one reported by Viles and Sieracki (69). Only the parts of each image which were well focused were analyzed. Initially, a rollingball background subtraction with a radius of 20 pixels was applied to remove illumination from large, diffuse detrital particles. An example of a picture after background subtraction is shown in Fig. 2A. We then calculated a smoothed secondorder derivative of the picture by convolution with a Marr-Hildreth matrix, $M(69)$ :

$$
M=\left|\begin{array}{rrrrr}
0 & -3 & -5 & -3 & 0 \\
-3 & 2 & 6 & 2 & -3 \\
-5 & 6 & 12 & 6 & -5 \\
-3 & 2 & 6 & 2 & -3 \\
0 & -3 & -5 & -3 & 0
\end{array}\right|
$$

The resulting derivative is shown in Fig. 2B. Cell edges were found by thresholding the second derivative with an absolute threshold of zero, thus defining the cell edge as being at the inflection point (i.e., the zero point for the second derivative [Fig. 2C]). Unavoidable noise in the picture showed up as a filigree pattern in the thresholded image (Fig. 2C). To prevent noise patterns that accidentally touched the cells from being included in the cell outlines, a binary opening was performed. The opening operation (an erosion followed by a dilation, each with a neighbor count of three [56]) breaks up the filigree into small islands and leaves larger structures, such as cells, essentially unaltered (Fig. 2D). Not all objects in this picture are cells, however, so we needed a separate analysis to find which objects were actually cells. Viles and Sieracki (69) used an edge strength operator, but that approach was not reliable with the amount of noise we encountered in our pictures. Instead, we thresholded the second derivative with a value other than zero (e.g., 120) so that only objects with a very high second derivative were selected (Fig. 2E). The picture still included some noise, which was efficiently removed by a single erosion with a neighbor count of five (56). The resulting picture (Fig. 2F) contained points within structures that should be considered real cells. A comparison of Fig. 2D and F in which only the structures in Fig. 2D which are touched by objects in Fig. $2 \mathrm{~F}$ are selected (i.e., a binary "feature-and" operation [56]) distinguishes those features in Fig. 2D that are true cells (Fig. 2G). The resulting cell masks are shown superimposed on the original picture in Fig. $2 \mathrm{H}$.

The masks were used to demarcate pixels in the picture belonging to cells. The intensity values from the original unperturbed picture corresponding to those outlines were used for further calculations. Apparent cell volume was calculated on the basis of the best filling ellipsoid with the assumption that the unknown vertical axis was equivalent to the measured minor axis (i.e., that the cells are lying down on the filters). We thus got

$$
V=\frac{4 \pi}{3} a b^{2}
$$

where $V$ is cell volume and $a$ and $b$ are the major and minor axes, respectively, of the best filling ellipsoid. The resulting volume estimates are not as accurate as is possible with confocal techniques. Nonetheless, though the individual volume estimates could be biased, the relative changes in appraised average volumes should reflect equivalent changes in the averages of the real volumes.

The detected cells were classified as belonging to one of five different morphotypes by the following criteria. (i) A small coccoid cell has a cell area of $<0.35$ $\mu \mathrm{m}^{2}$ and the length of the major axis of its best fitting ellipsoid is $<1.8$ times that of the minor axis. (ii) A large coccoid cell has a cell area of $\geq 0.35 \mu \mathrm{m}^{2}$ and the length of the major axis is $<1.8$ times that of the minor axis. (iii) A small elongated cell has a cell area of $<0.35 \mu \mathrm{m}^{2}$ and the length of the major axis is $\geq 1.8$ times that of the minor axis. (iv) A large elongated cell has a cell area of $\geq 0.35 \mu \mathrm{m}^{2}$ and the length of the major axis is $\geq 1.8$ times that of the minor axis. (v) An irregular cell has a perimeter that is longer than 2.2 times the sum of the lengths of the axes of the best fitting ellipsoid regardless of cell size.

Three to six pictures of each probe were analyzed at every depth. Each picture contained from 5 to 500 cells, depending on the nature of the probe and the amount of the water sample filtered through the particular well. A total of more than 20,000 stained cells were thus counted and analyzed in 213 pictures.

The pseudocolored pictures (see Fig. 2 and 5) were assembled with Adobe Photoshop version 3.0 (Adobe, Mountain View, Calif.).

\section{RESULTS}

Oxygen conditions prior to investigations. Annual variations in oxygen concentrations during 1993 are shown by the isopleth diagram in Fig. 1D. An influx of oxygenated bottom water occurred in late December of the previous year, but anoxia was reestablished in the bottom waters from early April. From April until mid-June, the oxycline shoaled to a depth of $13.5 \mathrm{~m}$, where it then remained relatively constant throughout the summer period. No influx of bottom water was observed in 1993, as was indicated by salinity measurements associated with the oxygen determinations shown in Fig. 1D (data not shown).

Oxygen and sulfur compounds. Concentration profiles for $\mathrm{O}_{2}$ and $\mathrm{H}_{2} \mathrm{~S}$ are shown in Fig. 3A. Oxygen decreased abruptly at a depth of around $14.5 \mathrm{~m}$; however, trace amounts (3 to 10 $\mu \mathrm{M})$ were found down to a depth of $16.5 \mathrm{~m}$. An inverted pattern was found for $\mathrm{H}_{2} \mathrm{~S}$, with concentrations increasing with depth from 5 to $35 \mu \mathrm{M}$ at between 15.5 and $17.5 \mathrm{~m}$ to nearly $400 \mu \mathrm{M}$ at $23 \mathrm{~m}$.

A broad peak for $\mathrm{S}^{0}$ was found in the transition zone from 14.5 to $18 \mathrm{~m}$, with a maximum of $0.6 \mu \mathrm{M}$ at a depth of $15.5 \mathrm{~m}$, where $\mathrm{O}_{2}$ and $\mathrm{H}_{2} \mathrm{~S}$ were both present in small amounts (Fig. 3A). A similar peak for $S^{0}$ has been observed in the transition zone between oxygenated and sulfidic waters in the Cariaco 


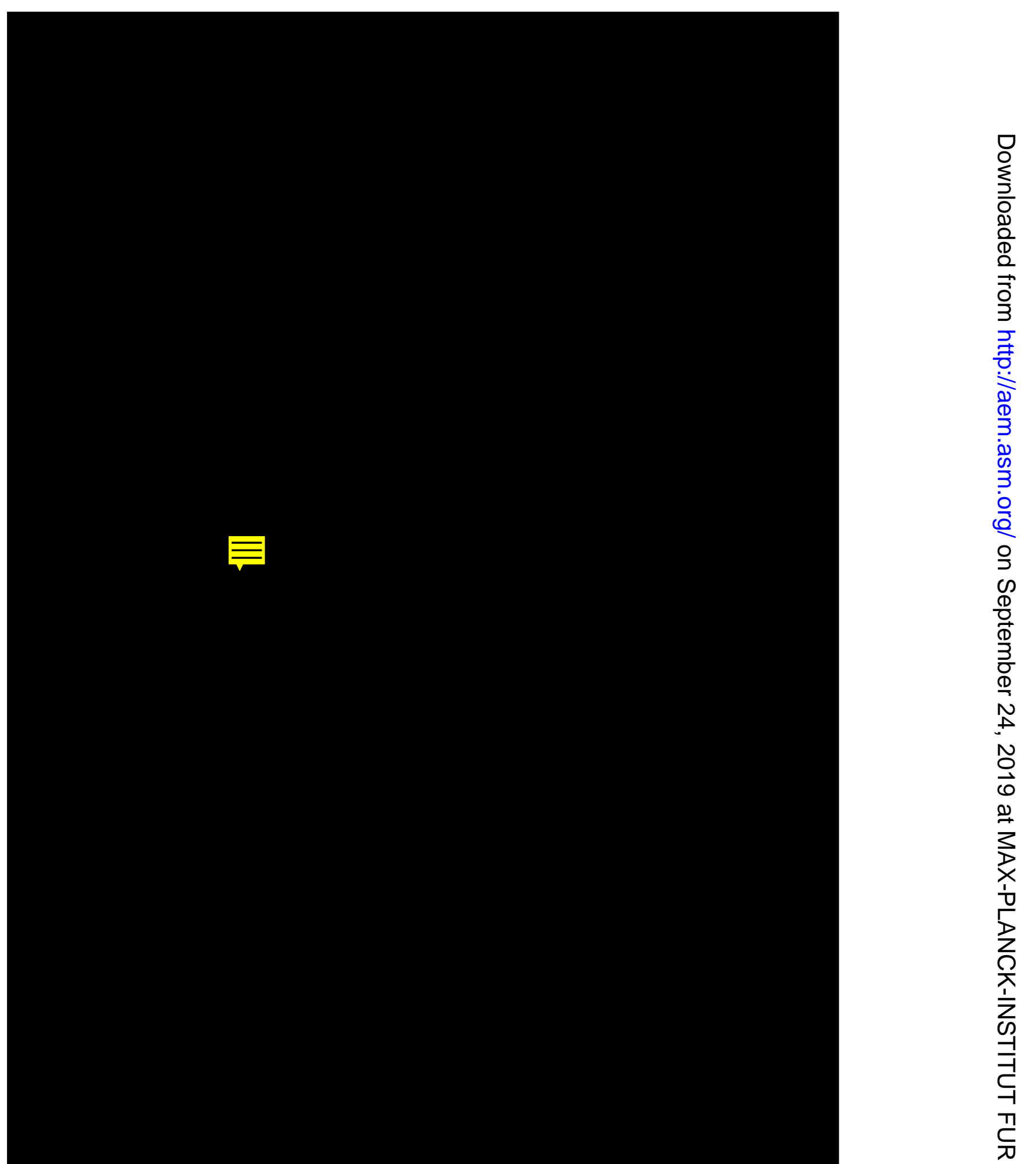

FIG. 2. Principle of the applied image analysis algorithm. This flow diagram shows the same cutout of a picture of cells stained with EtBr after application of the different procedures in the utilized image analysis algorithm. For an explanation, see Materials and Methods. The scale is the same as that in Fig. 5. 

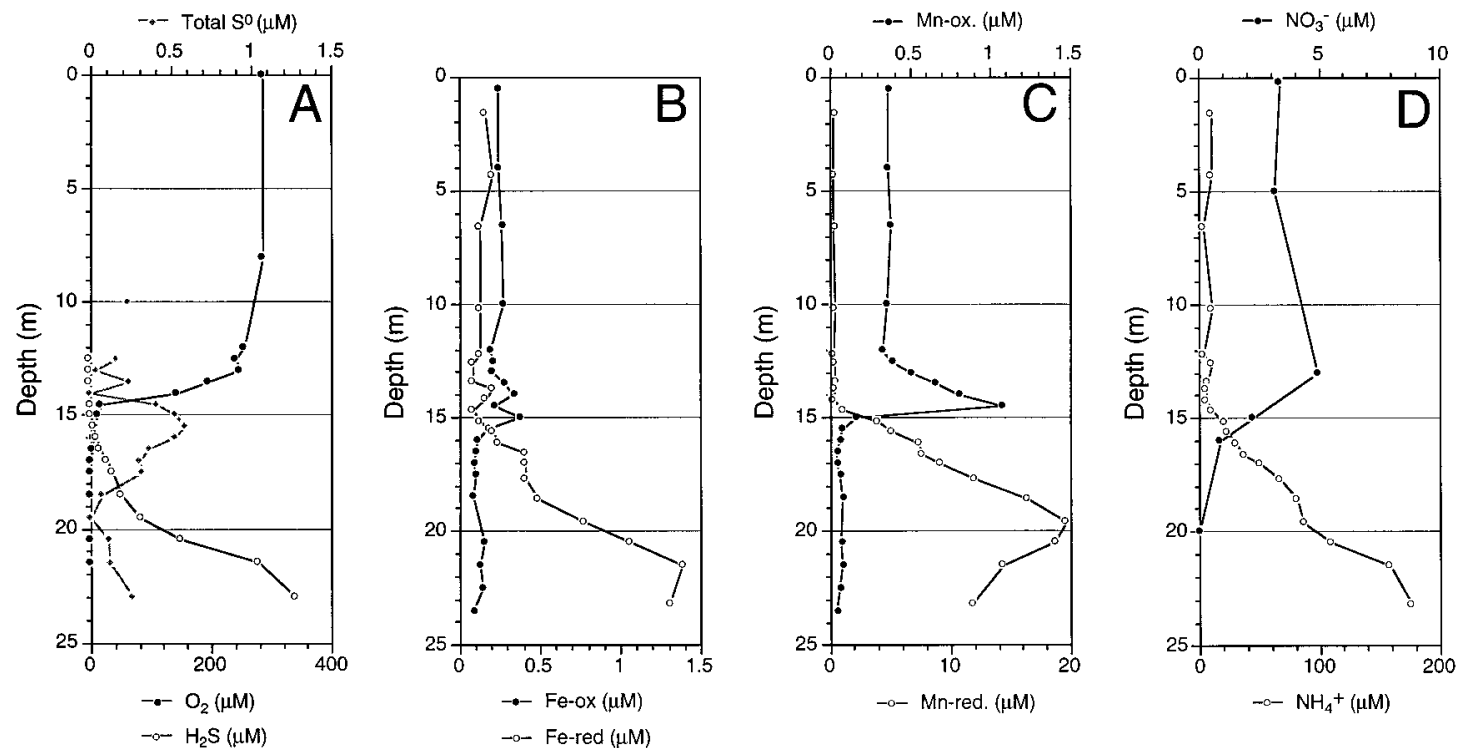

FIG. 3. Chemical gradients in the water column. (A) Concentrations of oxygen, hydrogen sulfide, and zero valence sulfur by depth. (B) Concentrations of particulate, presumably oxidized, iron (Fe-ox) and dissolved reduced iron (Fe-red) by depth. (C) Concentrations of oxidized particulate manganese (Mn-ox.) and reduced dissolved manganese (Mn-red.) by depth. (D) Concentrations of combined nitrate and nitrite and of ammonia by depth.

Trench (30) and in the Black Sea chemocline (36). In the latter case, the peak was reported to be associated with the presence of autotrophic sulfide oxidizers. Thiosulfate and tetrathionate concentrations were below their detection limits $(5$ and $1 \mu \mathrm{M}$, respectively) at all depths.

Iron and manganese. Dissolved ferrous iron, $\mathrm{Fe}^{2+}$, was undetectable above a depth of $14.5 \mathrm{~m}$ (Fig. 3B). Below $15 \mathrm{~m}$ deep, the concentration increased linearly to $1.5 \mu \mathrm{M}$ at $22 \mathrm{~m}$ deep. The concentration of particulate iron was slightly elevated $(\approx 0.3 \mu \mathrm{M})$ at around $15 \mathrm{~m}$, probably mainly because of $\mathrm{Fe}(\mathrm{III})$ hydroxides. Dissolved manganese (primarily $\mathrm{Mn}^{2+}$ ) was exclusively detected beneath $14.0 \mathrm{~m}$ deep, from which depth it increased linearly to a broad peak of $20 \mu \mathrm{M}$ at $20 \mathrm{~m}$ deep (Fig. 3C). Particulate manganese [primarily $\mathrm{Mn}(\mathrm{III})$ and $\mathrm{Mn}(\mathrm{IV})$ oxides] was found in a well-defined band at a depth of from 13 to $15 \mathrm{~m}$, with a prominent peak of $1.1 \mu \mathrm{M}$ occurring at $14.5 \mathrm{~m}$ (Fig. 3C).

Nitrogen compounds. The combined concentration profile of the oxidized nitrogen compounds (Fig. 3D) reflected primarily the distribution of nitrate, as the concentration of nitrite is likely to be negligible $(4,47)$. Nitrate was thus found only above the chemocline, with a maximum concentration of $5 \mu \mathrm{M}$ at a depth of $13 \mathrm{~m}$. The concentration was reduced within the chemocline and undetectable at $20 \mathrm{~m}$ deep. Ammonia was present at all depths, but the concentration increased linearly in and below the chemocline (Fig. 3D).

Direct rate measurements. Sulfate reduction was not detected at any depths by the isotope tracer method, even in samples that had been degassed with $\mathrm{N}_{2}$ to remove all traces of $\mathrm{O}_{2}$. The detection limit was approximately $1 \mu \mathrm{mol}$ of $\mathrm{SO}_{4}{ }^{2-}$ liter $^{-1}$ day $^{-1}$, provided the radiolabelled sulfide produced was not reoxidized to $\mathrm{SO}_{4}{ }^{2-}$ during the time course of the experiment. In situ oxygen respiration was likewise below our detection limit $\left(\approx 1 \mu \mathrm{mol}\right.$ liter $\left.^{-1} \mathrm{~h}^{-1}\right)$ at all depths.

Physical gradients. Gradients of temperature and salinity within the water column are shown in Fig. 4A. Both parameters remained constant down to a depth of about $13 \mathrm{~m}$, below which the salinity increased whereas the temperature decreased. The water density was calculated from salinity and temperature measurements and increased almost linearly from $13 \mathrm{~m}$ deep to about $21 \mathrm{~m}$ deep (Fig. 4A). The density gradient determines the mechanical resistance to mixing by eddy turbulences. An approximate value for the vertical turbulent mixing coefficient, $K_{z}$, for any depth $(z)$ can be estimated from the density gradient as follows $(23,39,41)$ :

$$
K_{z}=\frac{a_{0}}{\sqrt{\left(\frac{g}{\rho_{z}}\right)\left(\frac{\partial \rho}{\partial z}\right)_{z}}}
$$

where $a_{0}$ is the input of energy to the basin via internal waves, $g$ is the gravitational acceleration constant $\left(9.80 \mathrm{~m} \mathrm{~s}^{-2}\right), \rho_{z}$ is the density at depth $z$, and $(\partial \rho / \partial z)$ is the density gradient at depth $z$. A value of $0.0002 \mathrm{~cm}^{2} \mathrm{~s}^{-2}$ was chosen for $a_{0}$, as it falls between values calculated for completely restricted basins $\left(0.0001 \mathrm{~cm}^{2} \mathrm{~s}^{-2}\right)(39)$ and the open ocean $\left(0.001 \mathrm{~cm}^{2} \mathrm{~s}^{-2}\right)(41)$. Calculated values for $K_{z}$ are shown in Fig. 4B.

The estimated turbulent mixing coefficient was relatively constant for all depths between 13.3 and $21 \mathrm{~m}$ (shaded area on Fig. 4B), averaging $0.0015 \mathrm{~cm}^{2} \mathrm{~s}^{-1}$, which is at least 2 orders of magnitude higher than molecular diffusion coefficients (42). We can consequently ignore molecular diffusion and instead use the turbulent mixing coefficient as an apparent vertical diffusion coefficient for all dissolved species between depths of 13.3 and $21 \mathrm{~m}$.

Process rates calculated from chemical profiles. Rates of chemical processes occurring in a particular layer of the water column can be estimated from the difference between the influx of substances to the layer and their efflux from the layer, assuming that the observed chemical concentration profiles represent steady-state conditions. We can use the concentration gradients to calculate the flux $(J)$ of the various compounds with Fick's first law of diffusion:

$$
J=-D \frac{\partial C}{\partial z}
$$

where $D$ is the apparent diffusion coefficient and $\partial C / \partial z$ is the 

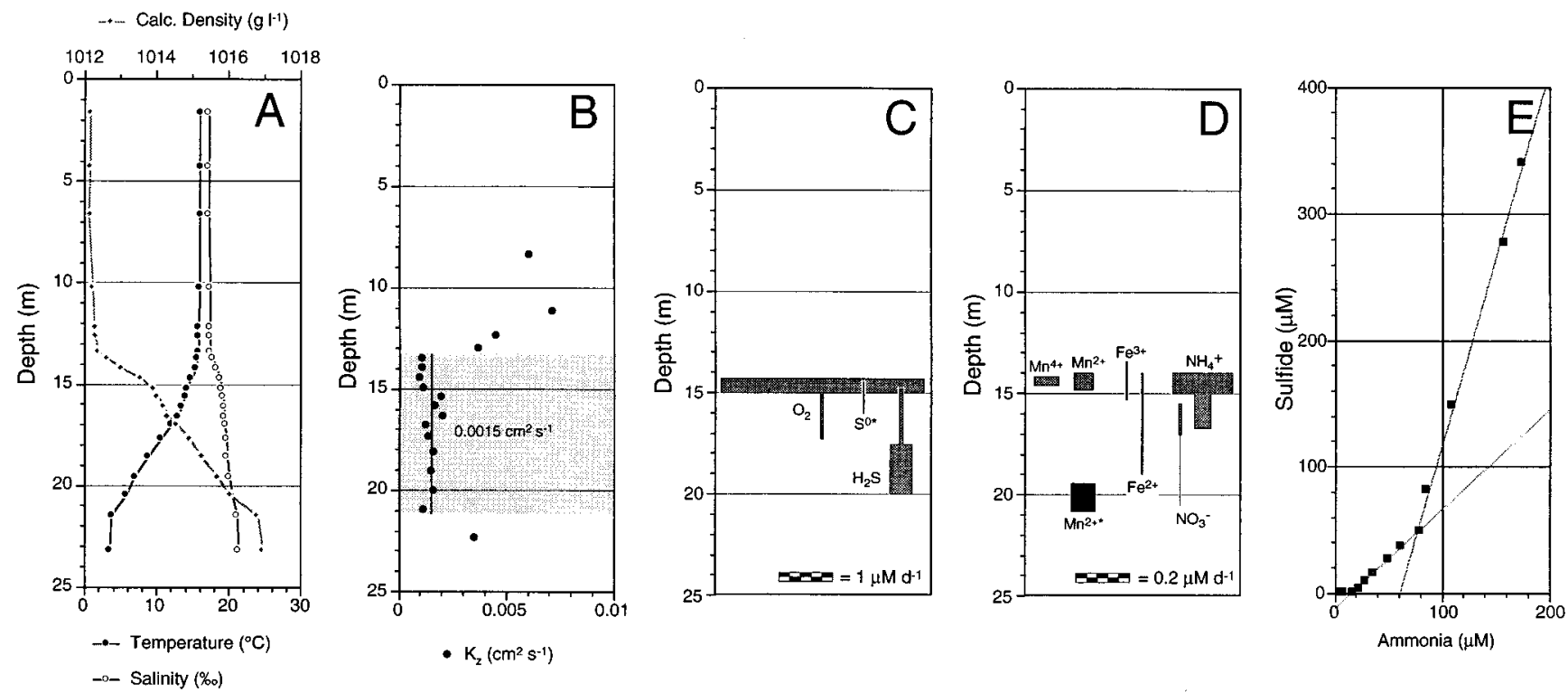

FIG. 4. Physical gradients and estimated process rates. (A) Physical gradients of temperature and salinity and the calculated (Calc.) water densities by depth. (B) The estimated effective diffusion coefficient, $K_{z}$, by depth, as calculated by the equation in the "Physical gradients" paragraph in Results. The region between 13.4 and $21.0 \mathrm{~m}$ where $K_{z}$ is presumed to be constant is indicated by shading. An average value of $0.0015 \mathrm{~cm}^{2} \mathrm{~s}^{-1}$ is indicated by a vertical line. (C and D) Process rates derived from concentration profiles under a steady state assumption. The widths of the shaded boxes indicate consumption rate estimates for the various compounds at given depths. The darker shaded boxes for $\mathrm{S}^{0}$ and $\mathrm{Mn}^{2+}$ (marked with asterisks) indicate regions of production and not consumption. Horizontal scale bars for the rate estimates are included for each of the panels. (E) Sulfide concentration at a given depth plotted against ammonia concentration ( $\mathbf{\square})$ at the same depth. Lines represent linear regressions. The regression line for low ammonia concentrations has a slope of $0.78\left(r^{2}=0.998\right)$, whereas the regression line for higher ammonia concentrations has a slope of $2.94\left(r^{2}=0.996\right)$. The latter is in nice agreement with the concurrent ammonia and sulfide production because of the anaerobic degradation of organic matter (see the text).

concentration gradient (8). We limit the flux calculations to the depth range from 13.3 to $21 \mathrm{~m}$, where the mixing coefficient was well constrained and we thus can use an average mixing coefficient of $0.0015 \mathrm{~cm}^{2} \mathrm{~s}^{-1}$ (see above). The turbulent mixing coefficient above a depth of $13.3 \mathrm{~m}$ is at least 1 order of magnitude larger than that below this depth (Fig. 4B) (which is why all chemical concentrations are essentially constant in the upper water levels). The total vertical fluxes of major electron acceptors and electron donors and their derived rates of consumption and production are presented in Table 1 . The molecular process rates were further converted to millimoles of electrons being transferred so that the total redox balance of the system could be evaluated. The downward flux of oxygen below a depth of $13.3 \mathrm{~m}$ was twice the combined upward fluxes of sulfide and ammonia. Given that sulfide and ammonia carry twice the number of electrons of oxygen, the fluxes balanced remarkably well, as the downward flux of electron acceptors was matched by an almost equivalent upward flux of electron donors. $\mathrm{Fe}$ and $\mathrm{Mn}$ were insignificant in the overall redox balance (Table 1).

Oxygen. The main zone of oxygen respiration was found in a narrow band at a depth of from 14.3 to $15.0 \mathrm{~m}$. The respiration rates were estimated from the concentration profile to be $\approx 3.8 \mu \mathrm{mol} \mathrm{liter}{ }^{-1}$ day $^{-1}$. However, limited oxygen respiration also occurred at greater depths, as is illustrated in Fig. 4C, giving a total rate of $2.76 \mathrm{mmol}$ of $\mathrm{O}_{2} \mathrm{~m}^{-2}$ day $^{-1}$.

Hydrogen sulfide. Hydrogen sulfide was the most important inorganic electron donor diffusing up from the sediment (Table 1). Oxidation rates calculated from the concentration profiles revealed some $\mathrm{H}_{2} \mathrm{~S}$ oxidation $\left(0.08 \mu \mathrm{mol} \mathrm{liter}^{-1}\right.$ day $\left.^{-1}\right)$ at depths of from 14.8 to $17.5 \mathrm{~m}$ (Fig. 4C). However, the main zone of $\mathrm{H}_{2} \mathrm{~S}$ oxidation was found at between 17.5 and $20 \mathrm{~m}$ deep $\left(0.4 \mu \mathrm{mol} \mathrm{liter}^{-1}\right.$ day $\left.^{-1}\right)$, which was more than $3 \mathrm{~m}$ below the zone of maximum oxygen consumption (Fig. 4C). This

TABLE 1. Flux of electron donors and electron acceptors from surface water to sediment

\begin{tabular}{|c|c|c|c|c|c|}
\hline Compound & $\begin{array}{l}\text { Total flux into sediment } \\
\left(\mathrm{mmol} \mathrm{m}{ }^{-2} \text { day }^{-1}\right)\end{array}$ & $\begin{array}{l}\text { Electrons per } \\
\text { molecule }\end{array}$ & $\begin{array}{l}\text { Electron acceptor equivalent } \\
\quad\left(\mathrm{mmol} \mathrm{m}^{-2} \text { day }^{-1}\right)\end{array}$ & $\begin{array}{l}\text { Electron donor equivalent } \\
\quad\left(\mathrm{mmol} \mathrm{m}{ }^{-2} \text { day }^{-1}\right)\end{array}$ & $\begin{array}{l}\text { Balance of electrons } \\
\left(\mathrm{mmol} \mathrm{m}^{-2} \text { day }^{-1}\right)\end{array}$ \\
\hline Oxygen & 2.762 & 4 & 11.048 & & \\
\hline Sulfide & -1.222 & 8 & & -9.774 & \\
\hline Zero valence sulfur & 0.007 & 6 & & 0.039 & \\
\hline Fe (oxidized) & 0.006 & 1 & 0.006 & & \\
\hline $\mathrm{Fe}$ (reduced) & -0.004 & 1 & & -0.004 & \\
\hline Mn (oxidized) & 0.030 & 2 & 0.059 & & \\
\hline Mn (reduced) & 0.055 & 2 & & 0.109 & \\
\hline $\mathrm{NO}_{3}^{-}$ & 0.017 & 8 & 0.137 & & \\
\hline $\mathrm{NH}_{4}^{+}$ & -0.273 & 8 & & -2.183 & \\
\hline Total for all compounds & & & 11.251 & -11.813 & -0.562 \\
\hline
\end{tabular}


finding was confirmed when the $\mathrm{H}_{2} \mathrm{~S}$ concentration was plotted against salinity to reveal zones of consumption. The $\mathrm{H}_{2} \mathrm{~S}$ concentration is not proportional to salinity for datum points for depths from between 17.5 and $20 \mathrm{~m}$, which indicates that the apparent consumption is not merely an artifact due to increased eddy diffusion (data not shown).

The net process rates for zero valence sulfur, $\mathrm{S}^{0}$, which was assumed to be soluble, were low (Table 1) (Fig. 4C). Elemental $S$ could nevertheless be an important intermediate with a high turnover rate if the measured $S^{0}$ was not soluble but was contained in bacterial cells, such as chemolithotrophs and/or photosynthetic sulfur bacteria (see Discussion).

Iron and manganese. The low process rate and small valence shift of iron exclude the possibility that it played an important role as electron carrier between the surface and bottom (Fig. 4D). Manganese was present in higher amounts and its process rates are significant; however, as only two electrons per molecule are carried, it is of minor importance in the total electron budget. Reduced manganese is apparently produced in the sulfide oxidation zone at a depth of around 19.4 to $20.8 \mathrm{~m} \mathrm{(0.06}$ $\mu \mathrm{mol}$ liter ${ }^{-1}$ day $^{-1}$ ), more than $4 \mathrm{~m}$ above the sediment surface (Fig. 4D), whereas it is oxidized in the zone of maximum oxygen consumption at a depth of 14 to $14.8 \mathrm{~m}(0.06 \mu \mathrm{mol}$ liter ${ }^{-1}$ day $^{-1}$ ).

Ammonia and nitrate. The $\mathrm{NH}_{4}{ }^{+}$profile showed a linear increase with depth from about $14 \mathrm{~m}$ (Fig. 3D), and the region of $\mathrm{NH}_{4}{ }^{+}$oxidation was thus found mainly in the $\mathrm{O}_{2}$ consumption zone between 14 and $15 \mathrm{~m}\left(0.19 \mu \mathrm{mol} \mathrm{liter}^{-1}\right.$ day $\left.^{-1}\right)$, with some activity extending down to a depth of $16.7 \mathrm{~m}(0.05 \mu \mathrm{mol}$ liter ${ }^{-1}$ day $^{-1}$ ) (Fig. 4D). Ammonia oxidation is thus an important process in the system, given that each molecule transfers eight electrons upon complete oxidation to nitrate.

The maximum nitrate concentration was found at a depth of $13 \mathrm{~m}$, which indicates a zone of $\mathrm{NO}_{3}{ }^{-}$production, in agreement with the observed ammonium oxidation. Because of the poor resolution of the nitrate profile, however, we cannot estimate nitrification rates in the $\mathrm{O}_{2}$ consumption zone. For the same reason, the calculated nitrate consumption below a depth of $15 \mathrm{~m}$ (Table 1) should be considered a minimum estimate. Because of the high concentrations of ammonia relative to those of nitrate in the nitrate consumption zone (Fig. 3D), the product of this reduction (dinitrogen or ammonia) could not be determined. In the electron balance calculations (Table 1), we have, for simplicity, assumed that nitrate was reduced to ammonia. This pathway represents the maximum contribution of nitrate as an electron acceptor.

Phytoplankton. Surface water samples were characterized by a high abundance of different diatoms, mainly Skeletonema costatum ( 850 cells ml $\mathrm{ml}^{-1} \approx 12 \mathrm{ng}$ of $\mathrm{C} \mathrm{ml} \mathrm{m}^{-1}$ ), Chaetoceros socialis $\left(60\right.$ cells $\mathrm{ml}^{-1} \approx 1.6 \mathrm{ng}$ of $\left.\mathrm{C} \mathrm{ml}^{-1}\right)$, Ditylum brightwelli ( 26 cells ml ${ }^{-1} \approx 40 \mathrm{ng}$ of $\mathrm{C} \mathrm{ml}^{-1}$ ), and Thalassiosira rotula ( 47 cells $\mathrm{ml}^{-1} \approx 18 \mathrm{ng}$ of $\mathrm{C} \mathrm{ml}^{-1}$ ). Their abundance decreased rapidly with depth, however, and they were rarely found beneath $6 \mathrm{~m}$. Another numerically prominent phototroph- $\mathrm{Mi}$ cromonas pusilla - was found in relatively high numbers $(>150$ cells $\mathrm{ml}^{-1}$ ) at all water depths, with a conspicuous maximum abundance in the chemocline at depths from 12 to $18 \mathrm{~m}$ $\left(>1,000\right.$ cells $\left.\mathrm{ml}^{-1}\right)$ (data not shown).

EtBr staining and in situ hybridization. Both EtBr staining and the general eubacterial probe $(338 \mathrm{~F})$ revealed a large population of bacteria in the water column $\left(>10^{6}\right.$ cells $\left.\mathrm{ml}^{-1}\right)$. Individual cells stained with the probe (385R) for the delta subdivision of proteobacteria, which includes most sulfate reducers, were occasionally observed above the chemocline (Fig. $5)$. These were apparently individual cells that were not attached to detrital particles. Staining with nonhybridizing con-

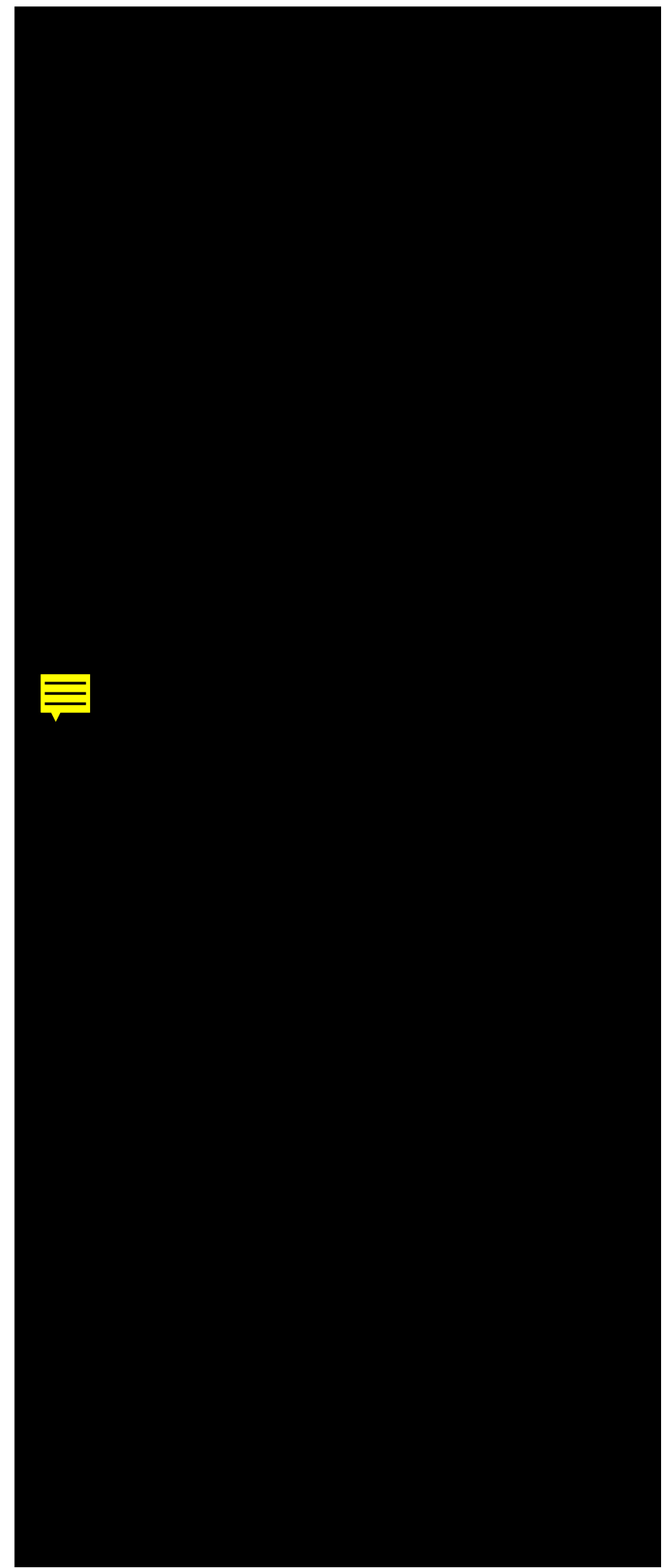

FIG. 5. Representative pictures of water samples from different depths after in situ hybridization with a fluorescein-labelled (green) probe for all eubacteria, $338 \mathrm{~F}$, and a tetramethylrhodamine-labelled (red) probe for the delta group of proteobacteria, 385R. The blue-white composite scale bar in the picture for 20.5 $\mathrm{m}$ equals $10 \mu \mathrm{m}$. The scale bar applies to all the images. 

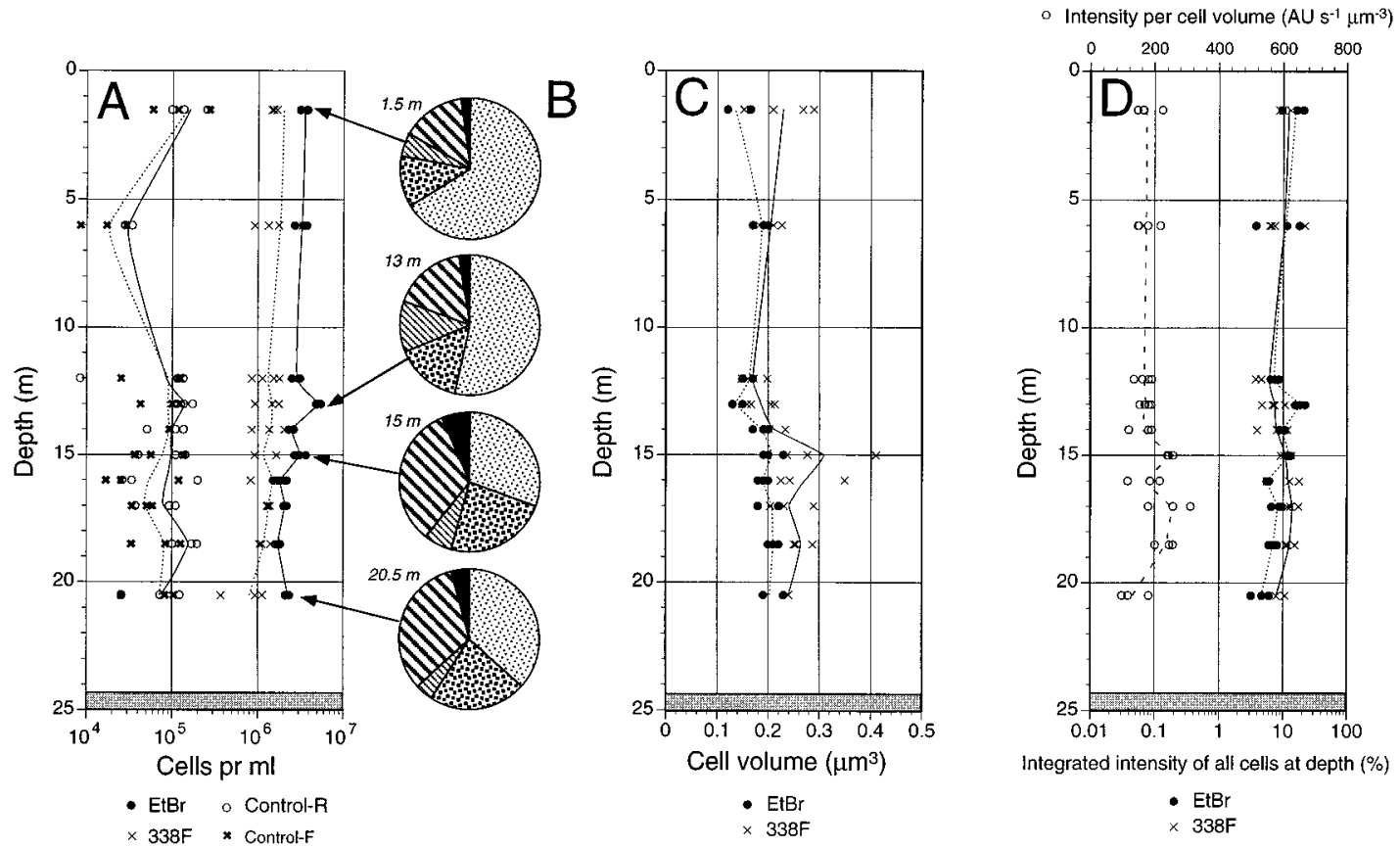

FIG. 6. Cells were stained with $\mathrm{EtBr}$ and a general probe for all eubacteria, 338F. Each point represents an analysis of a single picture. The average values for all analyzed pictures at a given depth are connected by broken and solid lines. (A) Density of cells in the water column that were stained with EtBr (solid line), $338 \mathrm{~F}$ (broken line), tetramethylrhodamine-labelled control (Control-R; solid line), and fluorescein-labelled control (Control F; broken line). (B) Morphology of EtBr-stained cells at given depths indicated by arrows to panel A. The sizes of the pie sections correspond to the relative abundances of five different morphotypes: 0 , small coccoid cells; ; see Materials and Methods. (C) Average cell volumes of EtBr-stained cells (broken line) and 338F-stained cells (solid line). (D) The total fluorescence intensities of all cells stained with EtBr (broken line) (extracted DNA) and with 338F (solid line) (extracted RNA) are shown. The fluorescence intensities per volume (broken line) (growth rate) are also shown. AU, arbitrary units.

trol probes to evaluate the abundance of autofluorescent cells and the effect of unspecific staining did not reveal cells with similar shapes. Below the chemocline, 385R-stained cells were much more frequently observed and mostly had a characteristic rod shape (Fig. 5). The intensity of cells stained with fluorescent oligonucleotide probes was low, however, and autofluorescent detritus and subcellular particles were abundant, which limited the detectability of bacterial subpopulations. We also had problems with a fairly rapid bleaching of the fluorophores that, combined with the low intensity and high background, made manual cell counts unreliable and unfeasible.

Image analysis. As a direct consequence of the problems with low fluorescence intensity and bleaching, we decided to use quantitative image analysis to improve sensitivity and to avoid possible operator bias when samples stained with specific probes were compared with samples stained with nonsense control probes. The cells were detected by a two-step procedure in which (i) the cell edges were defined by the inflection point of the second derivative of the intensity and (ii) the magnitude of the second derivative was used to distinguish between true cells and background noise (see Materials and Methods) (Fig. 2).

Cells stained with EtBr and with the eubacterial probe. Direct counts of EtBr-stained cells were surprisingly constant throughout the water column (approximately $2 \times 10^{6}$ to $4 \times$ $10^{6}$ cells $\mathrm{ml}^{-1}$ ) (Fig. 6A), given the pronounced stratification of the chemical environment (Fig. 3) and processes (Fig. 4). Counts of positive cells with the eubacterial probe, $338 \mathrm{~F}$, likewise gave very constant cell densities of around $1 \times 10^{6}$ to $2 \times$ $10^{6}$ cells $\mathrm{ml}^{-1}$ (Fig. 6A). It was thus possible to detect approximately $50 \%$ of all EtBr-stained cells with the eubacterial probe by image analysis. Visual observation was less successful, in that less than $20 \%$ of all EtBr-stained cells were counted with the eubacterial probe. In a similar study of a less eutrophic, stratified tropical water column, Golfo Dulce in Costa Rica, we found much lower bacterial cell counts, with only a small fraction (10 to $20 \%$ ) of the bacteria being detectable with the general eubacterial probe even after image analysis (17).

Control probes. Fluorescein- and rhodamine-labelled negative control probes (Control-F and Control-R) gave consistently lower cell counts of around $10^{5}$ cells ml $\mathrm{ml}^{-1}$ (Fig. 6A). It can thus be assumed that the vast majority of the cells stained by the eubacterial probe or by EtBr were true cells. The relatively high blank counts with the negative control probes are an unavoidable side effect of the highly efficient and sensitive image analysis algorithms used.

Cell morphology and volume estimates. The pie charts in Fig. 6B show the relative abundances of different morphotypes in the water column. A notable shift towards larger and more elongated cells was observed in the chemocline at a depth of between 13 and $15 \mathrm{~m}$.

Cell volume assessments based on rotational ellipsoids are shown in Fig. 6C for EtBr- and 338F-stained cells. The average volumes of EtBr-stained cells were significantly lower than the volumes of probe-stained cells. The discrepancy was expected, as the EtBr-stained cells which could not be stained with the eubacterial probe were generally the smallest cells, which presumably contained low amounts of ribosomes. A significant increase in average cell volume was observed beneath the chemocline for both $\mathrm{EtBr}$ - and oligonucleotide probe-stained cells (Fig. 6C). Increased average bacterial cell size under anoxic conditions has been observed previously (15). It has 
been ascribed to lower rates of predation by higher organisms which otherwise tend to reduce the average bacterial size in oxic waters (16). An alternative explanation could be that the cells are growing more rapidly in the chemocline, so the percentage of starved dwarf cells is lower.

RNA concentration in single cells. An estimate of the relative RNA concentrations in single cells was obtained by dividing the integrated fluorescence intensity by the calculated cell volume and exposure time (Fig. 6D) (12). This calculation showed a constant average intensity down to a depth of $14 \mathrm{~m}$, below which we found regions with a higher intensity per cell volume. The estimated average RNA concentration has been assumed in culture experiments to be proportional to the growth rate (50). The correlation coefficients appear to be species dependent, however, so it is not possible to obtain a general growth rate estimate for natural mixed populations from the fluorescence intensity (40). However, regions of increased fluorescence intensity could indicate a higher microbial activity.

The total intensity of all cells at a given depth expressed as a percentage of the total intensity of all cells at all depths is likewise shown in Fig. 6D. The total intensity corresponds to the depth profile of extractable RNA (see Fig. 3A of the accompanying article [65]).

Sulfate-reducing bacteria. There are three possible problems when rRNA-targeted oligonucleotide probes are used in microbial ecology: (i) false negatives, (ii) false positives, and (iii) false conclusions about the physiology of the detected organisms. These problems arise because of the limited length of the probe sequence as well as the limited length of the target molecule, and they appear to be most difficult to solve for general probes that are supposed to detect diversified phylogenetic groups of bacteria sharing important common traits, such as the probe, 385R, for sulfate-reducing bacteria within the delta group of the proteobacteria. This probe was originally reported to be inclusive for most groups of sulfate-reducing bacteria belonging to the delta group of proteobacteria (1). However, when used stringently, as in this study, it does not stain all dissimilatory sulfate reducers. All known members of the genera Desulfovibrio, Desulfobulbus, and Desulfomonas contain the full target sequence; however, some members of the genera Desulfobacter and Desulfomicrobium and all known members of the genera Desulfobacterium, Desulfosarcina, Desulfobacula, Desulfococcus, Desulfoarculus, and Desulfomonile contain at least a single mismatch within the target sequence (most frequently an A instead of a $\mathrm{G}$ in position 395 of the $16 \mathrm{~S}$ rRNA sequence) which will strongly reduce the labelling intensity, as has been verified with the reference strains listed above. The probe will also not stain the sulfate reducers which do not belong to the delta group of proteobacteria, such as members of the genera Desulfotomaculum (spore formers belonging to the low-GC, gram-positive group) and Archaeoglobus (thermophilic archaebacteria).

The stringent hybridization conditions used have thus reduced the target group to a subset of the sulfate reducers within the delta group of proteobacteria; however, the stringent conditions are necessary to reduce the possibility of false positives. Nevertheless, some non-sulfate-reducing bacteria carry the complete target sequence and thus cannot be excluded. A search of the database of the Ribosomal Database Project, which contains $>3,00016 \mathrm{~S}$ rRNA sequences (45), with the program CHECK_PROBE revealed that all the potentially false positives belong to one of three groups: (i) non-sulfatereducing bacteria from the delta group of proteobacteria, i.e., some myxobacteria from the genera Chondromyces and Polyangium; (ii) actinomycetes from the high-GC group of gram- positive bacteria from the genera Frankia and Actinopolyspora; and finally (iii) members of the genus Thermoanaerobacter and three Clostridium species (C. fervidum, C. stercorarium, and $C$. thermolacticum) from the low-GC group of the gram-positive bacteria. Myxobacteria colonize the dung of herbivores and bark and rotting wood and do not grow in seawater (3). Frankia spp. are obligate nitrogen-fixing root endosymbionts of woody plants (3). The Thermoanaerobacter species and the three Clostridium species occur in volcanic areas, self-heated soil, and compost or cattle manure (3). Essentially, marine gram-positive bacteria are limited to sea bottom sediments and amount to approximately $1 \%$ of the gram-negative population in this habitat (58). Therefore, gram-positive bacteria which carry the target sequence are unlikely to occur in significant numbers in the water column.

Furthermore, detection of gram-positive bacteria by in situ hybridization generally requires special preparations (i.e., a lysozyme and/or a proteinase $\mathrm{K}$ digestion and use of special detergents in a separate incubation before or after ethanol dehydration) to render the cell membranes permeable to the oligonucleotide probes $(19,27,28)$. Such steps were not included in our protocol, so it is highly unlikely that gram-positive bacteria could have been detected, even if they had been present in the samples. As none of the known proteobacteria outside the delta group carry the target sequence for probe 385 , it seems most likely that the 385 probe-positive cells observed in the water column were phylogenetically related to the known sulfate-reducing bacteria in the delta group of proteobacteria. For a closer identification of bacterial populations, using this probe together with more specific probes for subgroups of sulfate-reducing genera appeared to be the best strategy.

Total counts of all cells with all shapes stained with $385 \mathrm{R}$ and with a nonhybridizing control probe, Control-R, are shown in Fig. 7A. The cell counts with both probes were very similar, except for a slight difference for counts beneath the chemocline. However, visual observations indicated that the dominating positive cell type with the $385 \mathrm{R}$ probe was a long slim rod-shaped bacterium that was found in large numbers in the upper part of the chemocline (Fig. 5). Larger ellipsoid cells represented the predominant 385R-positive cell type at greater depth. Cells shaped like vibrios were found occasionally but were never dominant. We consequently sorted the identified cells into different classes according to morphological criteria. The class for large (area, $\geq 0.35 \mu \mathrm{m}^{2}$ ) elongated (the length of the major axis of best fitting ellipsoid is $\geq 1.8$ times that of the minor axis) bacteria contained most of the true positive cells with the 385R probe, whereas only a few cells were found with the control probe. The cell counts of large elongated cells with both probes are shown in Fig. 7B. Equivalent counts were obtained with both probes down to a depth of $14 \mathrm{~m}$. Below this depth, the $385 \mathrm{R}$ probe counts were 3 to 10 times higher than the control probe counts. We thus detected a significant bacterial subpopulation which belonged to the delta group of proteobacteria and which was found only within and beneath the chemocline. The upper range of this bacterial distribution extended into the oxic zone above $16.5 \mathrm{~m}$, and thus these bacteria were subjected to trace amounts of oxygen ( 3 to 10 $\mu \mathrm{M})$. The morphology of the 385R-stained cells found in this oxic region was relatively uniform, i.e., rod-shaped cells that were long ( 2 to $3 \mu \mathrm{m})$, thin $(0.5$ to $0.7 \mu \mathrm{m})$, and straight. It should be noted that these rod-shaped cells were apparently not attached to detrital particles. Detrital particles with a postulated anoxic center have previously been used to explain the presence of sulfate reducers in otherwise oxic environments (59).

Cell volume and activity. The average cell volumes of large, 

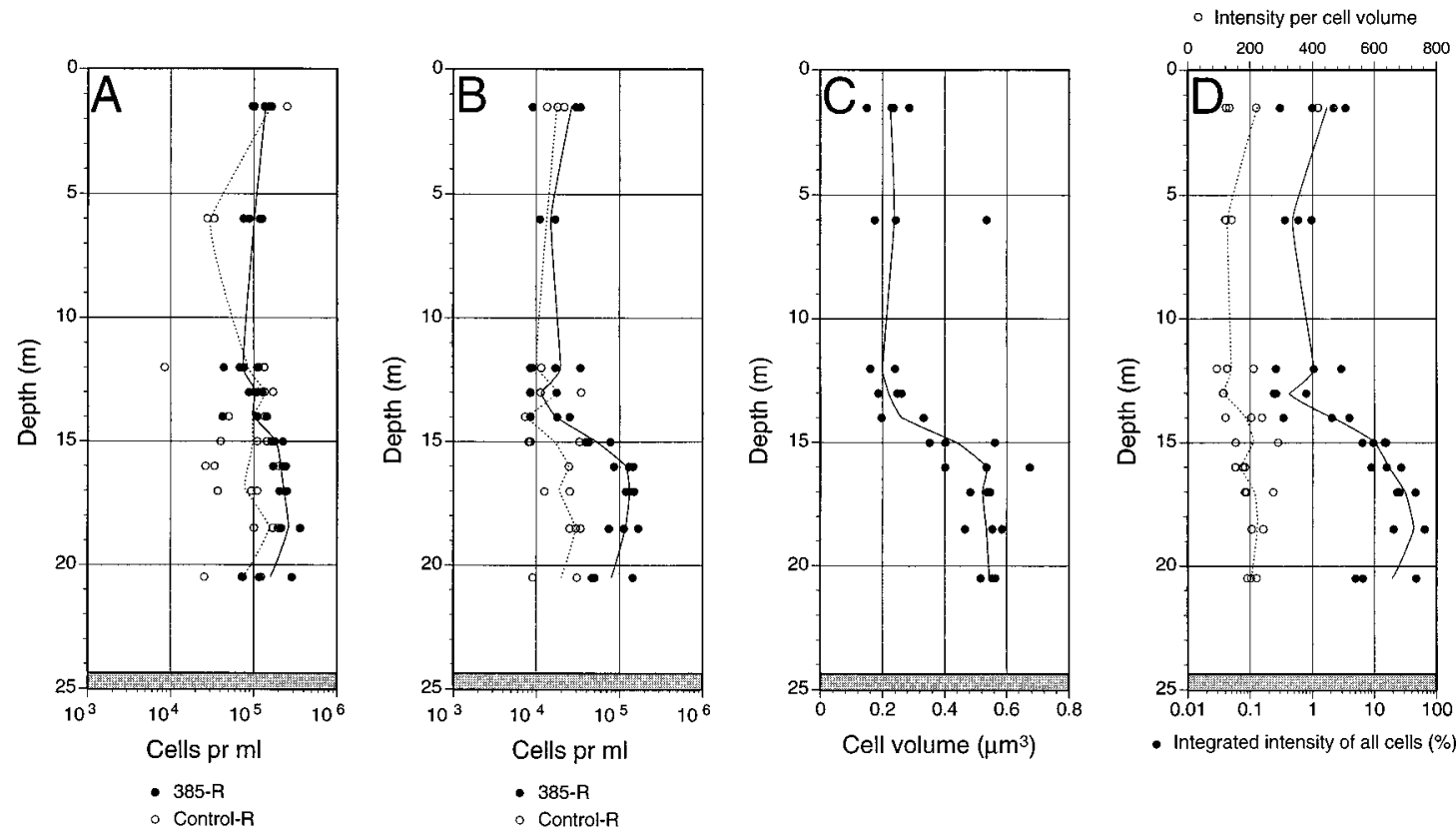

FIG. 7. Probe 385 for the delta group of proteobacteria compared with a nonhybridizing control probe. Each point represent an analysis of a single picture. Average values for all analyzed pictures at a given depth are connected by broken or solid lines. (A) Summarized cell counts for all morphotypes stained with 385R (solid line) and tetramethylrhodamine control probe (Control-R) (broken line). (B) Cell counts for one morphotype (large elongated) stained with 385R (solid line) and tetramethylrhodamine control probe (Control-R) (broken line). (C) Average cell volume for large elongated cells stained with 385R. (D) The integrated 385R staining intensities of large elongated cells at a given depth as a percentage of the total intensity of those cells at all depths (solid line) and the intensities per cell volume (in arbitrary units per second per micrometer ${ }^{3}$ ) for large elongated cells (broken line).

385R-positive elongated cells (Fig. 7C) more than doubled beneath the chemocline, which also indicated the presence of a distinct population of sulfate-reducing bacteria. The intensity per volume of these cells (Fig. 7D) also increased beneath the chemocline, though the increase was less pronounced. The combined effect of larger cell numbers (Fig. 7B), larger cell size (Fig. 7C), and a slightly higher intensity per cell volume beneath the chemocline (Fig. 7D) resulted in a pronounced increase in the total intensity of all large elongated cells stained with the 385R probe within the chemocline (Fig. 7D). Less than $1 \%$ of the total intensity was found in elongated cells at depths above the chemocline, and there was a more than 20 -fold increase across the chemocline. This figure corresponds to the amount of $385 \mathrm{R}$ probe-positive, PCR-amplified rRNA from the water column (see Fig. 3B of the accompanying article [65]).

Specific probes for different genera of sulfate-reducing bacteria. It was not possible to identify any significant portion of the 385R-stained delta bacteria with six different probes (13) for subgroups of sulfate-reducing bacteria. We especially wanted to identify the dominant long slender rod-shaped cells in the upper part of the chemocline, but to no avail. We found, however, some large ellipsoid cells that were positive with Desulfobacterium probe $221\left(\sim 10^{3}\right.$ to $10^{4}$ cells $\left.\mathrm{ml}^{-1}\right)$ at depths of below 18 to $20 \mathrm{~m}$ as well as single positive cells with the Desulfovibrio and Desulfobacter probe $\left(\leq 10^{3}\right.$ cells $\left.\mathrm{ml}^{-1}\right)$. The numbers were, nevertheless, too low to be reliably quantified, given the high counts with the control probe.

We found very high numbers of weakly positive cells $\left(10^{5}\right.$ to $10^{6}$ cells $\mathrm{ml}^{-1}$ ) with the Desulfobulbus probe on some filters of samples from depths around that of the chemocline, 15 to 17 $\mathrm{m}$, but such numbers were not found on all filters from those depths. A possible explanation could be that an aggregate(s) of nonmotile Desulfobulbus or Desulfobulbus-related sulfate-re- ducing bacteria could have been disrupted during handling, which could give rise to highly erratic cell counts. It should be noted, however, that we never observed such aggregates.

With the 814 probe and the general 804 probe, we had problems with staining efficiency for reference cells and thus concluded that these probes are not suited for in situ hybridizations, although they work very well with membrane blots of isolated nucleic acids $(13,54,65)$.

\section{DISCUSSION}

The detailed biogeochemical study of the water column was carried out to characterize the redox sequence in the water column and to assess which bacterial reactions should be expected to dominate at different depths (i.e., redox zones). In what follows, the term chemocline will designate the zone of oxygen consumption at a depth of from 14 to $17.5 \mathrm{~m}$ that is the upper part of the pycnocline.

The basis for the development of bottom water anoxia in Mariager Fjord is the physical stratification that results from the occasional introduction of dense seawater through the long shallow inlet of the threshold fjord (Fig. 1B and C). As oxygen is depleted from the bottom water, the oxycline rises until a steady state in which $\mathrm{O}_{2}$ consumption in the water column and sediment is balanced by the downward transport of $\mathrm{O}_{2}$. The seasonal monitoring of $\mathrm{O}_{2}$ suggested that a steady state was established before our sampling (Fig. 1D).

Nitrate concentrations in the top $14 \mathrm{~m}$ of the water column were lower than $6 \mu \mathrm{M}$, and nitrate penetrated only a few meters deeper than $\mathrm{O}_{2}$. Nitrate reduction was thus restricted to a narrow zone in the upper part of the pycnocline. The same was true for dissimilatory $\mathrm{Mn}$ and Fe reduction, as the oxide levels were low and the buildup of $\mathrm{Mn}^{2+}$ and $\mathrm{Fe}^{2+}$ was small relative to that of $\mathrm{NH}_{4}{ }^{+}$. Furthermore, $\mathrm{H}_{2} \mathrm{~S}$, which reacts spon- 
taneously with Mn or Fe oxides, would compete with Mn- or Fe-reducing bacteria for any reactive $\mathrm{Mn}$ or $\mathrm{Fe}$ oxides raining into the bottom waters (6).

Although there was a good quantitative agreement between the rates of $\mathrm{O}_{2}$ and $\mathrm{H}_{2} \mathrm{~S}$ consumption calculated from concentration gradients (Table 1), there was a pronounced separation $(>3 \mathrm{~m})$ between the depths at which the two processes occurred (Fig. 4C). The rate calculations are associated with some uncertainties due to the assumption of a steady state and in the calculations of the eddy diffusion coefficient. Nevertheless, that $\mathrm{H}_{2} \mathrm{~S}$ is in fact missing from the top of the anoxic water column becomes evident when the $\mathrm{NH}_{4}{ }^{+}$and $\mathrm{H}_{2} \mathrm{~S}$ concentrations are compared (Fig. 4E). Organic matter, with an elemental composition defined by the standard Redfield ratio, being oxidized by sulfate reduction has the stoichiometry (21)

$$
\begin{gathered}
\left(\mathrm{CH}_{2} \mathrm{O}\right)_{106}\left(\mathrm{NH}_{3}\right)_{16} \mathrm{H}_{3} \mathrm{PO}_{4}+53 \mathrm{SO}_{4}{ }^{2-} \rightarrow 106 \mathrm{HCO}_{3}{ }^{-}+ \\
16 \mathrm{NH}_{3}+\mathrm{H}_{3} \mathrm{PO}_{4}+53 \mathrm{H}_{2} \mathrm{~S}
\end{gathered}
$$

with the release of $\mathrm{NH}_{4}{ }^{+}$and $\mathrm{H}_{2} \mathrm{~S}$ being at a ratio of 1:3.3. At a depth of from 15.5 to $18.5 \mathrm{~m}, \mathrm{NH}_{4}{ }^{+}$and $\mathrm{H}_{2} \mathrm{~S}$ accumulated at a considerably higher ratio, 1:0.8, while the ratio in the deepest part of the basin was 1:2.9, in close agreement with that predicted above. As argued above, no other respirations than sulfate reduction could explain the accumulation of $\mathrm{NH}_{4}{ }^{+}$, and a consumption of $\mathrm{H}_{2} \mathrm{~S}$ is, thus, most likely to explain the discrepancy in the upper strata.

Unknown dissolved electron carrier. With the assumption of a steady state, the close agreement between the rates of $\mathrm{O}_{2}$ reduction and $\mathrm{H}_{2} \mathrm{~S}$ oxidation (Table 1) suggested that $\mathrm{H}_{2} \mathrm{~S}$ was oxidized to $\mathrm{SO}_{4}{ }^{2-}$, with $\mathrm{O}_{2}$ being the terminal oxidant. The spatial separation of the processes, however, calls for an intermediate electron carrier linking the two processes. We can estimate the necessary concentration change from the oxygen reduction zone to the sulfide oxidation zone for a dissolved electron carrier by assuming that it carries the sulfide electron flux, $F\left(9.8 \mathrm{mmol}\right.$ of electrons $\mathrm{m}^{-2}$ day $\left.^{-1}\right)$ (Table 1$)$, across a gap, $\Delta z$, of $3 \mathrm{~m}$ at the apparent diffusion coefficient, $K_{z}$, determined above. Using Fick's first law of diffusion $[\Delta C=(\Delta z F)$ / $K_{z}$ ], we get a concentration difference $(\Delta C)$ across the gap of $\approx 2.3 \mathrm{mM}$ electrons. The dissolved oxidized form of such a compound would thus have to be present in a high concentration (corresponding to $2.3 \mathrm{mM}$ electron equivalents) in the surface water. The concentration should then decrease linearly from the zone of oxygen reduction to the zone of sulfide oxidation, while the reduced form of the electron carrier increases linearly in abundance to $2.3 \mathrm{mM}$ electrons beneath the zone of sulfide oxidation. None of the investigated inorganic compounds meet these criteria, and it seems unlikely that an alternative redox pair of electron carriers should be present in adequate amounts.

Particulate electron carrier. The input of potential oxidants $\mathrm{Mn}$ and Fe oxides to the sulfidic zone is difficult to quantify because of their particulate form. The calculated molecular diffusion rates do not apply to particulate species, which can sink through the water column at substantially higher rates if they have a higher density than the surrounding water. Nonetheless, neither iron nor manganese can constitute the missing link, as the reduced versions, $\mathrm{Mn}^{2+}$ and $\mathrm{Fe}^{2+}$, which have to diffuse upwards, are present only in limited amounts. We are thus unable to identify (or suggest a plausible candidate for) an abiotic electron carrier that can transport reducing equivalents from the region of sulfide oxidation to the region of oxygen reduction.

Anoxygenic $\mathrm{H}_{2} \mathrm{~S}$ oxidation by microorganisms. Anoxygenic phototrophs, such as those found in the chemocline of the
Black Sea (52), could provide an alternative explanation for the apparent sulfide consumption at a depth of from between 17.5 and $20 \mathrm{~m}$. Only low amounts of light are available beneath the chemocline (less than $0.05 \%$ of incident light, as extrapolated from the measured light attenuation in the upper $10 \mathrm{~m}$ ), but many phototrophic sulfur bacteria are known to grow at very low light intensities (49). However, microscopic examination of filtered water samples did not reveal any conspicuous population of pigmented (possibly fluorescent) bacteria at this depth range.

Microorganisms might also transport the electrons between the zones of sulfide oxidation and oxygen reduction. Bacteria would, potentially, by changing their buoyancy, be able to move between different depths at a speed that exceeds the estimated eddy diffusion. Diurnal migration of the purple sulfur bacterium Chromatium okenii has been observed in meromictic Lake Belovod, in which the population showed diurnal vertical displacements of up to $2 \mathrm{~m}$ on bright days (62). Such an organism could take up $\mathrm{H}_{2} \mathrm{~S}$ in the $\mathrm{H}_{2} \mathrm{~S}$ oxidation zone, make a partial oxidation to elemental sulfur, store the sulfur intracellularly as sulfur granules, and move up to the oxic zone, where the sulfur would be oxidized to sulfate with molecular oxygen. The small peak of zero valence sulfur, $\mathrm{S}^{0}$, could indicate the presence of autotrophic sulfide-oxidizing bacteria with intra- or extracellular deposits of elemental sulfur granules. Such bacteria could be either chemolithotrophs or the abovementioned phototrophic sulfur bacterium.

Sulfide precipitation. The lack of $\mathrm{H}_{2} \mathrm{~S}$ accumulation in anoxic environments where sulfate reduction is the dominant respiratory process is a common feature in marine sediments and can be explained by the reaction of $\mathrm{H}_{2} \mathrm{~S}$ with reactive $\mathrm{Fe}$ oxides, producing the solid reduced phases of $\mathrm{FeS}, \mathrm{FeS}_{2}$, and $S^{0}(6,67)$. Hence, if most of the reduced inorganic metabolites in the water column originated from the sediments on the bottom and sides of the basin, a retention of reduced sulfur phases in the sediments could cause a decoupling of $\mathrm{H}_{2} \mathrm{~S}$ and $\mathrm{NH}_{4}{ }^{+}$transport, as has been observed. In a permanently anoxic basin, the precipitation of reduced $\mathrm{S}$ is limited by the sedimentation of reactive $\mathrm{Fe}$ oxides, but a reaeration of the basin, as occurred in December 1992 (Fig. 1D), could cause a reoxidation of the surface sediments, leaving a pool of reactive $\mathrm{Fe}$ oxides that is only gradually titrated by $\mathrm{H}_{2} \mathrm{~S}$.

Although the precipitation of reduced sulfur phases may explain the variations in the $\mathrm{NH}_{4}{ }^{+} / \mathrm{H}_{2} \mathrm{~S}$ accumulation ratio, it does not involve $\mathrm{O}_{2}$ consumption and, thus, does not explain the apparent balance of $\mathrm{O}_{2}$ and $\mathrm{H}_{2} \mathrm{~S}$ consumption rates (Table 1). This explanation therefore requires that an unknown, possibly heterotrophic process contribute to most of the oxygen consumption in the chemocline.

EtBr staining and in situ hybridization. The novel direct hybridization in the filtration device eliminated a possible loss of cells during the transfer of cells from the filters to glass slides and/or subsequent washing steps found in previous protocols (31). However, direct hybridization appears to require the use of aluminum oxide filters, as ordinary polycarbonate filters give too high a background fluorescence after hybridization.

We chose $\mathrm{EtBr}$ as a general nucleic acid stain because (i) it gives a very high, virtually unbleachable fluorescent signal; (ii) it works well with aluminum oxide filters (71); (iii) it exclusively stains double-stranded DNA and RNA; and (iv) it is excited by green light and emits red light, thus minimizing problems with chromatic aberrations otherwise known to occur with such blue fluorescent dyes as 4',6-diamidino-2-phenylindole (DAPI). (Chromatic aberrations become particularly aggravating when an attempt to infer cell sizes from digital pictures is made, as all 
cells have to be well focused.) We used both DAPI and EtBr in a previous study of bacterial populations in a tropical stratified water column (17) and found the obtained cell counts to be virtually identical.

Image analysis. The application of fluorescent oligonucleotide probes to quantify bacterial subpopulations in complex natural samples by in situ hybridization is generally impeded by low staining intensity and high autofluorescence. It is thus absolutely necessary to use negative nonhybridizing control probes as well as known reference strains to evaluate the staining efficiency. It is furthermore important to avoid a possible bias due to the subjective evaluations of the experimenter. There are two ways to do this safely: (i) by a blind experiment in which samples stained with positive and negative probes are mixed and evaluated by an unknowing observer (e.g., see reference 51) and (ii) by an automated digital image analysis in which the same analysis algorithms are applied to positively as well as negatively stained samples. An advantage of the latter approach is the additional information about cell size, morphology, and staining intensity which can easily be obtained. However, conventional one-step thresholding as most often applied in the image analysis of pure cultures will not work with natural samples because of the large differences in intensities for different cell types. An additional complication is the need to evaluate clumped cells. Since some bacteria might preferably grow in microcolonies, we cannot assume that population estimates for free-living bacteria can be extrapolated to also include cells living in clumps or on detrital particles (11). The method presented here overcomes these problems by using the zero point of the second derivative to define cell boundaries and a threshold limit to distinguish between noise and true cells. By adjusting the threshold limit, it is possible to change the sensitivity of the analysis to include more or less faint objects and yet the cell sizes measured on the basis of inflection points will remain unchanged by the detection limit. A further morphological classification of the detected cells based on size and shape can be used to identify subpopulations with a particular shape, even if the overall cell counts are hardly any different from the counts with negative control probes.

Detection limit. Even though the detection limit for in situ hybridization with fluorescent probes is theoretically a single cell, it is for practical purposes defined by the number of autofluorescent particles in the water column and the low-but significant-amounts of weakly fluorescent, unspecifically stained cells. Even nonfluorescent particles will pose a problem, as they tend to cloak the filters so that the bacteria are no longer deposited within a single focal plane. It thus becomes virtually impossible to do accurate imaging. In this study, we thus found a detection limit of around $10^{5}$ cells per ml for cells with various shapes, whereas cells with a defined, recurring shape could be detected down to about $10^{4}$ cells per ml (i.e., $\approx 1 \%$ of the total population).

Evaluation of rate estimates. Assuming that the cells detected with the delta probe shown in Fig. 7B are all sulfate reducers, we can estimate a potential maximum sulfate reduction rate on the basis of the observed $V_{\max }$ for known pure cultures. Maximum sulfate reduction rates of from 0.8 to 4.2 mmol of S g of dry cell mass ${ }^{-1} \mathrm{~h}^{-1}$ have been reported for pure cultures of different Desulfovibrio and Desulfobacter spp. (70). Using the observed cell densities of $10^{5}$ cells ml $\mathrm{ml}^{-1}$ beneath the chemocline (Fig. 7B) and an average cell volume of $0.5 \mu \mathrm{m}^{3}$ (Fig. 7C) at an estimated 5\% dry weight, we get a maximum sulfate reduction rate of 0.05 to $0.25 \mu \mathrm{M} \mathrm{S}$ day $^{-1}$ (800 to 4,200 $\mathrm{mmol}$ of S g ${ }^{-1} \mathrm{~h}^{-1} \times 24 \mathrm{~h} \mathrm{day}^{-1} \times 0.5 \mu \mathrm{m}^{3}$ cell $^{-1} \times 10^{5}$ cells $\left.\mathrm{ml}^{-1} \times 10^{3} \mathrm{ml} \mathrm{liter}^{-1} \times 0.05 \times 10^{-12} \mathrm{~g} \mathrm{~cm}^{-3}\right)$, which is significantly below the detection limit of $1 \mu \mathrm{M} \mathrm{S}$ day ${ }^{-1}$ for our in situ sulfate reduction rate measurements.

The heterotrophic activity as estimated on the basis of the chemical gradients at a depth of around $14.5 \mathrm{~m}$ was about $3.6 \mu \mathrm{M} \mathrm{O}_{2}$ day $^{-1}$. This estimate is likewise close to but still below the estimated detection limit $\left(24 \mu \mathrm{M} \mathrm{O}_{2}\right.$ day $\left.^{-1}\right)$ for our in situ incubations and thus could not be verified by direct measurements.

Comparison with traditional cultivation approaches. Mostprobable-number dilutions of sulfate-reducing bacteria on various carbon sources (lactate, acetate, and acetate and hydrogen) gave significantly lower bacterial densities than those found by in situ hybridizations (65). The highest bacterial counts (approximately $2 \times 10^{2}$ cells per $\mathrm{ml}$ ) were obtained from samples taken at a depth of $20 \mathrm{~m}$ and grown on lactate (see Fig. 3D in the accompanying article [65]). Cells were cultivated from the oxic parts as well but in much lower numbers. The relative distribution thus reflected the one found with the probes, i.e., at least an order of magnitude increase in cell counts around the chemocline (see Fig. 3D in reference $65)$. Fewer bacteria were found to grow on acetate, and the complete oxidizers thus appear to constitute a minor part of the total population of sulfate-reducing bacteria in the water column. Many acetate-utilizing, sulfate-reducing bacteria, such as Desulfobacter and Desulfosarcina spp., are nonmotile, which could at least partly explain their low abundance in the water column, and yet the same bacteria are likely to dominate in the deeper layers of the sediment, as has been observed in microbial mats (54).

Comparison with analysis of nucleic acid extracts. Nucleic acids extracted from water samples showed a fairly constant yield of DNA from all depths within in the water column, whereas the isolated 16S rRNA increased in concentration within and beneath the chemocline (see Fig. 3A in reference $65)$. These findings agree perfectly with those for integrated EtBr fluorescence (representing DNA) and integrated eubacterial probe intensity (representing 16S rRNA) (Fig. 6D) as well as with previous investigations of the general distribution of bacteria in Mariager Fjord (15).

The abundance of 385 probe-positive, PCR-amplified rRNA showed a pronounced increase in the chemocline (see Fig. 3B in reference 65) which was virtually identical to the total intensity increase found with the in situ hybridization data (Fig. 7D). The most abundant 385 probe-positive, PCR-amplified 16S rRNA sequence in the chemocline (depths of 14.5 and 16 $\mathrm{m}$ ) was a novel sequence that clearly belonged to a member of the delta group of proteobacteria and yet was unrelated to those of all known bacteria (65). The obtained partial sequence was thus not affiliated with any known genus of sulfate-reducing bacteria and contained base mismatches with the sequences of all genus-specific probes for sulfate-reducing bacteria (i.e., probe 660 for members of the genus Desulfobulbus, 687 for members of the genus Desulfovibrio, 814 for members of the genera Desulfococcus, Desulfosarcina, and Desulfobotulus, and 804 for members of the genera Desulfobacter and Desulfobacterium and the target groups of probe 814).

Potential physiology of the delta 385 probe-stained cells. The 385 probe-positive cells detected by in situ hybridization most likely belong to the delta subdivision of the proteobacteria, which contains the majority of all known sulfate-reducing bacteria together with several metal oxidizers and metal reducers. The relative distribution of 385 probe-stained cells agrees perfectly with counts of sulfate-reducing bacteria obtained with MPN cultures (65), supporting a possible classification for these cells as sulfate-reducing bacteria. However, even if these cells are able to grow heterotrophically by sulfate reduction, 
this possibility does not imply that they actually live as sulfate reducers in the water column. In fact, the region where the 385 probe-stained cells were most abundant was characterized by a net sulfide oxidation (Fig. 4C). Sulfate-reducing bacteria have been shown to be able to carry out a whole range of dissimilatory reactions, some of which involve the transition metals $\mathrm{Fe}$ and $\mathrm{Mn}(44,55)$ or nitrogen $(57)$, which are metabolized in the upper part of the depth range of these bacteria (Fig. 4D). They could thus be metal oxidizers or reducers and participate in the metabolism of nonsulfur compounds which occur in or just beneath the chemocline (Fig. 4D). They could also be involved in the metabolism of other sulfur compounds, perhaps being involved in the disproportionation of elemental sulfur $(44,66)$.

It was noted above that trace amounts of oxygen (3 to 10 $\mu \mathrm{M}$ ) were found down to a depth of $16.5 \mathrm{~m}$, so the upper region where the positive cells were detected was exposed to at least limited amounts of oxygen (microaerophiles). Oxygen respiration has been demonstrated for members of the genera Desulfovibrio and Desulfobulbus $(9,14,46)$. The specific probes for various sulfate reducers should have illuminated the nature of these bacteria, but the main 385 probe-positive morphotype (a long thin rod) was not stained by any of these probes. This outcome agrees well with the result of sequence analysis of reverse transcription-PCR-amplified rRNA extracted from the water column. The most dominant band which hybridized with the 385 probe belonged to the delta group of proteobacteria but was unrelated to any previously characterized genus within this group. All in all, the physiology of this possibly novel group of bacteria remains unknown.

Conclusions. The present study clearly demonstrates the potentials and limitations of in situ hybridization for studies of microbial populations. In situ hybridization enables accurate quantification of often unculturable, phylogenetically defined bacterial subpopulations. The sensitivity and objectivity can be greatly enhanced by digital image analysis and comparison with negative control probes. Image analysis, furthermore, makes it possible to use morphotype, cell size, and fluorescence intensity as sensitive markers for population shifts and to detect regions of increased activity. However, the amount of phylogenetic information obtained is limited because of the probe size, and the resulting ambiguity makes it very difficult to infer the physiological role of bacteria detected with general probes. This ambiguity can be clarified somewhat if the concurrent chemical processes are measured exhaustively, thus providing the basis for an educated guess. More specific probes based on known organisms in pure cultures frequently fail to detect the most dominant natural species. Nevertheless, excellent agreement between the qualitative outcomes of two different molecular methods and a traditional cultivation-based approach was observed (Fig. 6C in this paper and Fig. 3A in reference 65 and Fig. 7D in this paper and Fig. 3B and $C$ in reference 65). Both molecular methods (the in situ hybridization presented here and the analysis of extracted nucleic acids presented in reference 65) indicated the presence of unknown, possibly rod-shaped delta proteobacteria related to the sulfate-reducing bacteria but not affiliated with any of the known genera of sulfate-reducing bacteria. These bacteria were not restricted to anoxic waters, as significant numbers were detected in the upper part of the chemocline in the presence of small amounts of oxygen ( 3 to $10 \mu \mathrm{M})$. They were apparently not associated with detrital particles that could contain reduced microniches. This bacterial group related to the sulfate-reducing bacteria was found in a region of net sulfide oxidation, and most of them were found at positions intermediate to a zone of oxygen consumption and a zone of sulfide oxidation. The fluxes of electron acceptors (mainly $\mathrm{O}_{2}$ ) and electron donors (mainly
$\mathrm{H}_{2} \mathrm{~S}$ ) in the water column were found to balance well, although the zones of oxygen reduction and of sulfide oxidation were spatially separated. The pathways of electron transfer between these zones are unknown; hence, elucidation of the electron transfer mechanisms as well as of the physiological role of the unknown delta bacterium awaits future studies.

\section{ACKNOWLEDGMENTS}

We would like to thank the following persons for their essential help before, during, and after the cruise, for their technical assistance, and/or for their helpful discussions: Jens Gundersen, Sabine Hottenträger, Hans Jensen, Dan Jensen, Bo Barker Jørgensen, Rolf Lillebæk, Gerard Muyzer, Andreas Teske, and Cathrin Wawer. The paper also benefited from the comments of two anonymous reviewers. We would also like to thank Wayne Rasband for writing and continuously updating his excellent public domain image analysis program, NIH Image.

This work was generously supported by the Max Planck Society, Munich, Germany.

\section{REFERENCES}

1. Amann, R. I., B. J. Binder, R. J. Olson, S. W. Chrisholm, R. Devereux, and D. A. Stahl. 1990. Combination of 16S rRNA-targeted oligonucleotide probes with flow cytometry for analyzing mixed microbial populations. Appl. Environ. Microbiol. 56:1919-1925.

2. Bak, F., A. Shuhmann, and K.-H. Jansen. 1993. Determination of tetrathionate and thiosulfate in natural samples and microbial cultures by a new, fast and sensitive ion chromatographic technique. FEMS Microbiol. Ecol. 12: 257-264.

3. Balows, A., H. G. Trüper, M. Dworkin, W. Harder, and K.-H. Schleifer (ed.). 1992. The prokaryotes, 2nd ed. Springer Verlag, New York.

4. Brettar, I., and M. G. Höfle. 1993. Nitrous oxide producing heterotrophic bacteria from the water column of the central Baltic: abundance and molecular identification. Mar. Ecol. Prog. Ser. 94:253-265.

5. Canfield, D. E., and D. J. Des Marais. 1991. Aerobic sulfate reduction in microbial mats. Science 251:1471-1473.

6. Canfield, D. E., R. Raiswell, and S. Bottreel. 1992. The reactivity of sedimentary iron minerals towards sulfide. Am. J. Sci. 292:659-683.

7. Cline, D. E. 1969. Spectrophotometric determination of hydrogen sulfide in natural waters. Limnol. Oceanogr. 14:454-548.

8. Crank, J. 1983. The mathematics of diffusion. Clarendon Press, Oxford.

9. Dannenberg, S., M. Kroder, W. Dilling, and H. Cypionka. 1992. Oxidation of $\mathrm{H}_{2}$, organic compounds and inorganic sulfur compounds coupled to reduction of $\mathrm{O}_{2}$, or nitrite by sulfate-reducing bacteria. Arch. Microbiol. 158: 93-99.

10. DeLong, E. F. 1992. Archaea in coastal marine environments. Proc. Natl. Acad. Sci. USA 89:5685-5689.

11. DeLong, E. F., D. G. Franks, and A. L. Alldredge. 1993. Phylogenetic diversity of aggregate-attached vs. free-living marine bacterial assemblages. Limnol. Oceanogr. 38:924-934.

12. DeLong, E. F., G. S. Wickham, and N. R. Pace. 1989. Phylogenetic stains: ribosomal RNA-based probes for the identification of single cells. Science 243:1360-1363.

13. Devereux, R., M. D. Kane, J. Winfrey, and D. A. Stahl. 1992. Genus- and group-specific hybridization probes for determinative and environmental studies of sulfate-reducing bacteria. Syst. Appl. Microbiol. 15:601-609.

14. Dilling, W., and H. Cypionka. 1990. Aerobic respiration in sulfate reducing bacteria. FEMS Microbiol. Lett. 71:123-128.

15. Fenchel, T. 1990. Water column anoxia: vertical zonation of planktonic protozoa. Mar. Ecol. Prog. Ser. 62:1-10.

16. Fenchel, T., and B. J. Finlay. 1990. Anaerobic free-living protozoa: growth efficiencies and structure of anaerobic communities. FEMS Microbiol. Ecol. 74:269-276.

17. Ferdelman, T. G., D. E. Canfield, R. N. Glud, J. Gundersen, R. Lillebæk, J. Küver, N. B. Ramsing, B. Thamdrup, and C. Wawer. Unpublished data.

18. Ferguson, R. L., E. N. Buckley, and A. V. Palumbo. 1984. Response of marine bacterioplankton to differential filtration and confinement. Appl. Environ. Microbiol. 47:49-55.

19. Fischer, K., D. Hahn, W. Hönerlage, F. Schönholzer, and J. Zeyer. 1995. In situ detection of spores and vegetative cells of Bacillus megaterium in soil by whole cell hybridization. Syst. Appl. Microbiol. 18:265-273.

20. Fossing, H., and B. B. Jørgensen. 1989. Measurements of bacterial sulfate reduction in sediments: evaluation of a single-step chromium reduction method. Biogeochemistry (Dordrecht) 8:205-222.

21. Froelich, P. N., G. P. Klinkhammer, M. L. Bender, N. A. Luedtke, G. R. Heath, D. Cullen, P. Dauphin, D. Hammond, and B. Hartman. 1979. Early oxidation of organic matter in pelagic sediments of the eastern equatorial Atlantic: suboxic diagenesis. Geochim. Cosmochim. Acta 43:1075-1090.

22. Fründ, C., and Y. Cohen. 1992. Diurnal cycles of sulfate reduction under oxic 
conditions in cyanobacterial mats. Appl. Environ. Microbiol. 58:70-77.

23. Gargett, A. E. 1984. Vertical eddy diffusivity in the ocean interior. J. Mar. Res. 42:359-393.

24. Giovannoni, S. J., T. B. Britschgi, C. L. Moyer, and K. G. Field. 1990. Genetic diversity in Sargasso Sea bacterioplankton. Nature (London) 345: $60-63$.

25. Giovannoni, S. J., E. F. DeLong, T. M. Schmidt, and N. R. Pace. 1990. Tangential flow filtration and preliminary phylogenetic analysis of marine picoplankton. Appl. Environ. Microbiol. 56:2572-2575.

26. Grasshoff, K. 1983. Determination of oxygen, p. 419. In K. Grasshoff, M. Ehrhardt, and K. Kremling (ed.), Methods of seawater analysis. Verlag Chemie, Basel.

27. Hahn, D., R. I. Amann, W. Ludwig, A. D. L. Akkermans, and K.-H. Schleifer. 1992. Detection of microorganisms in soil after in situ hybridization with rRNA-targeted, fluorescently labelled oligonucleotides. J. Gen. Microbiol. 138:879-887.

28. Hahn, D., R. I. Amann, and J. Zeyer. 1993. Whole-cell hybridization of Frankia strains with fluorescence- or digoxigenin-labeled, 16S rRNA-targeted oligonucleotide probes. Appl. Environ. Microbiol. 59:1709-1716.

29. Hall, P. O. J., and R. C. Aller. 1992. Rapid, small-volume, flow injection analysis for $\Sigma \mathrm{CO} 2$ and $\mathrm{NH} 4+$ in marine and freshwaters. Limnol. Oceanogr. 37:1113-1119.

30. Hastings, D., and S. Emerson. 1988. Sulfate reduction in the presence of low oxygen levels in the water column of the Cariaco Trench. Limnol. Oceanogr. 33:391-396.

31. Hicks, R. E., R. I. Amann, and D. A. Stahl. 1992. Dual staining of natural bacterioplankton with 4',6-diamidino-2-phenylindole and fluorescent oligonucleotide probes targeting kingdom-level 16S rRNA sequences. Appl. Environ. Microbiol. 58:2158-2163.

31a.Isaksen, M., and A. Teske. Unpublished data.

32. Jensen, C. A., and K. Nielsen. 1993. Heavy metals, phosphorus and nitrogen in the sediment of Mariager Fjord, Kattegat, Denmark (Notat). Århus Amt, Miljøkontoret, Denmark.

33. Jørgensen, B. B. 1978. A comparison of methods for the quantification of bacterial sulfate reduction in coastal marine sediments. I. Measurement with radiotracer techniques. Geomicrobiol. J. 1:11-27.

34. Jørgensen, B. B. 1993. Sulfate reduction and thiosulfate transformations in a cyanobacterial mat during a diel oxygen cycle. FEMS Microbiol. Ecol. 13: 303-312.

35. Jørgensen, B. B., and F. Bak. 1991. Pathways and microbiology of thiosulfate transformations and sulfate reduction in a marine sediment (Kattegat, Denmark). Appl. Environ. Microbiol. 57:847-856.

36. Jørgensen, B. B., H. Fossing, C. O. Wirsen, and H. Jannasch. 1991. Sulfide oxidation in the Black Sea chemocline. Deep-Sea Res. 38:1083-1103.

37. Kogure, K., U. Simidu, and N. Taga. 1979. A tentative direct microscopic method for counting living marine bacteria. Can. J. Microbiol. 25:415-420.

38. Kogure, K., U. Simidu, and N. Taga. 1980. Distribution of viable marine bacteria in neritic seawater around Japan. Can. J. Microbiol. 26:318-323.

39. Landing, W. M., W. C. Burnett, W. B. Lyons, and W. H. Orem. 1991. Nutrient cycling and the biogeochemistry of manganese, iron and zinc in Jellyfish Lake, Palau. Limnol. Oceanogr. 36:515-525.

40. Lee, S., and P. F. Kemp. 1994. Single-cell RNA content of natural marine planktonic bacteria measured by hybridization with multiple 16S rRNAtargeted fluorescent probes. Limnol. Oceanogr. 39:869-879.

41. Lewis, B. L., and W. M. Landing. 1991. The biogeochemistry of manganese and iron in the Black Sea. Deep-Sea Res. 2:S773-S803.

42. Li, Y.-H., and S. Gregory. 1974. Diffusion of ions in sea water and in deep-sea sediments. Geochim. Cosmochim. Acta 38:703-714.

43. Lord, C. J. 1980 . The chemistry and cycling of iron, manganese and sulfur in salt marsh sediment. Ph.D. thesis. University of Delaware, Newark.

44. Lovley, D. R., and E. J. P. Phillips. 1994. Novel processes for anaerobic sulfate production from elemental sulfur by sulfate-reducing bacteria. Appl. Environ. Microbiol. 60:2394-2399.

45. Maidak, B. L., N. Larsen, M. J. McCaughey, R. Overbeek, G. J. Olsen, K. Fogel, J. Blandy, and C. R. Woese. 1994. The ribosomal database project. Nucleic Acids Res. 22:3485-3487.

46. Marschall, C., P. Frenzel, and H. Cypionka. 1993. Influence of oxygen on sulfate reduction and growth of sulfate-reducing bacteria. Arch. Microbiol. 159:168-173

47. Miljøkontorerne i Århus og Nordjyllands Amtskommuner. 1990. Mariager
Fjord 1985-89. Udvikling og status (technical report). Forvaltningerne for Teknik og Miljø, Århus, Denmark.

48. Millero, F., and Poisson. 1981. International one-atmosphere equation of state of seawater. Deep-Sea Res. 28:625.

49. Pfenning, N. 1978. The photosynthetic bacteria, p. 3-18. In R. K. Clayton and W. R. Sistrom (ed.), The photosynthetic bacteria. Plenum, New York.

50. Poulsen, L. K., G. Ballard, and D. A. Stahl. 1993. Use of rRNA fluorescence in situ hybridization for measuring the activity of single cells in young and established biofilms. Appl. Environ. Microbiol. 59:1354-1360.

51. Ramsing, N. B., M. Kühl, and B. B. Jørgensen. 1993. Distribution of sulfatereducing bacteria, $\mathrm{O}_{2}$, and $\mathrm{H}_{2} \mathrm{~S}$ in photosynthetic biofilms determined by oligonucleotide probes and microelectrodes. Appl. Environ. Microbiol. 59: 3840-3849.

52. Repeta, D. J., D. J. Simpson, B. B. Jørgensen, and H. W. Jannasch. 1989 Evidence for anoxygenic photosynthesis from the distribution of bacteriochlorophylls in the Black Sea. Nature (London) 342:69-72.

53. Richards, F. A. 1975. The Cariaco basin (trench). Oceanogr. Mar. Biol. Annu. Rev. 13:11-67.

54. Risatti, J. B., W. C. Capman, and D. A. Stahl. 1994. Community structure of a microbial mat: the phylogenetic dimension. Proc. Natl. Acad. Sci. USA 91: 10173-10177.

55. Roden, E. E., and D. E. Lovley. 1993. Dissimilatory Fe(III) reduction by the marine microorganism Desulfuromonas acetoxidans. Appl. Environ. Microbiol. 59:734-742.

56. Russ, J. C. 1990. Computer assisted microscopy. The measurement and analysis of images, 1st ed., vol. 1. Plenum Press, New York.

57. Seitz, H.-J., and H. Cypionka. 1986. Chemolithotrophic growth of Desulfovibrio desulfuricans with hydrogen coupled to ammonification of nitrate and nitrite. Arch. Microbiol. 146:63-67.

58. Sieburth, J. M. 1979. Grampositive aerobic epibacteria, p. 312-320. In J. M Sieburth (ed.), Sea microbes. Oxford University Press, New York.

59. Sieburth, J. M. 1993. C $_{1}$ bacteria in the water column of Chesapeake Bay, USA. I. Distribution of sub-populations of $\mathrm{O}_{2}$-tolerant, obligately anaerobic, methylotrophic methanogens that occur in microniches reduced by their bacterial consorts. Mar. Ecol. Prog. Ser. 95:67-80.

60. Skei, J. M. 1983. Permanently anoxic marine basins-exchange of substances across boundaries. Ecol. Bull. 35:419-429.

61. Skei, J. M. 1988. Framvaren—environmental settings. Mar. Chem. 23:209_ 218

62. Sorokin, Y. I. 1990. Interrelations between sulphur and carbon turnover in meromictic lakes. Arch. Hydrobiol. 66:391-446.

63. Standard protocol. 1994. Water analysis-determination of the sum of nitrite- and nitrate-nitrogen. Danish standard 223.

64. Stookey, L. L. 1970. Ferrozine, a new spectrophotometric reagent for iron. Anal. Chem. 42:779-781.

65. Teske, A., C. Wawer, G. Muyzer, and N. B. Ramsing. 1996. Distribution of sulfate-reducing bacteria in a stratified fjord (Mariager Fjord, Denmark) as evaluated by most-probable-number counts and denaturing gradient ge electrophoresis of PCR-amplified ribosomal DNA fragments. Appl. Environ. Microbiol. 62:1405-1415.

66. Thamdrup, B., K. Finster, J. W. Hansen, and F. Bak. 1993. Bacterial disproportionation of elemental sulfur coupled to chemical reduction of iron or manganese. Appl. Environ. Microbiol. 59:101-108.

67. Thamdrup, B., H. Fossing, and B. B. Jørgensen. 1994. Manganese, iron and sulfur cycling in a coastal marine sediment, Aarhus Bay, Denmark. Geochim. Cosmochim. Acta 58:5115-5129.

68. United Nations Educational, Scientific, and Cultural Organization. 1983. Algorithms for computation of fundamental properties of seawater. UNESCO Technical Papers in Marine Science 44. United Nations Educational, Scientific, and Cultural Organization.

69. Viles, C. L., and M. E. Sieracki. 1992. Measurement of marine picoplankton cell size by using a cooled, charge-coupled device camera with image-analyzed fluorescence microscopy. Appl. Environ. Microbiol. 58:584-592.

70. Widdel, F. 1988. Microbiology and ecology of sulfate- and sulfur-reducing bacteria, p. 469-585. In A. J. B. Zehnder (ed.), Biology of anaerobic microorganisms. John Wiley \& Sons, New York.

71. Williamson, F. A., and K. R. Palframan. 1989. An improved method for collecting and staining microorganisms for enumeration by fluorescence light microscopy. J. Microsc. (Oxford) 154:267-272. 


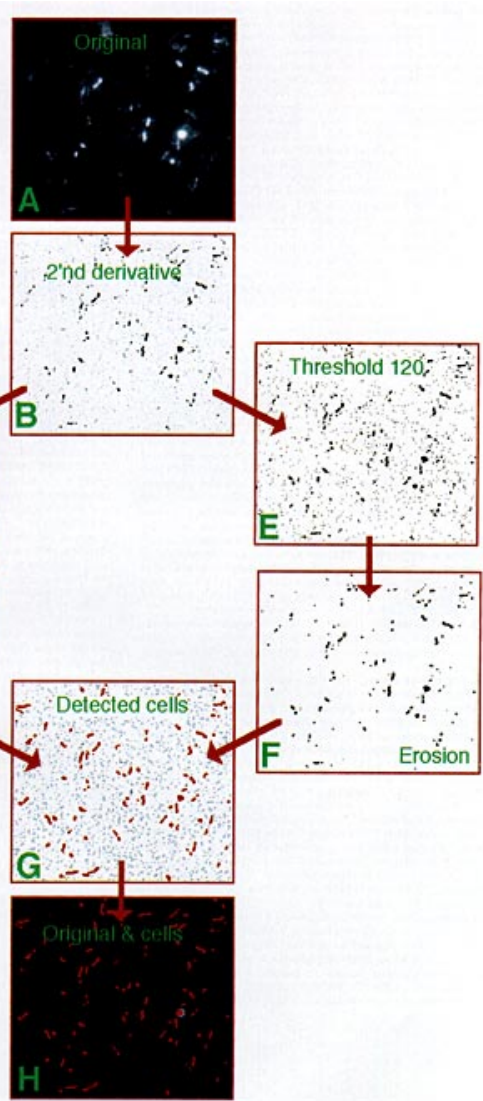



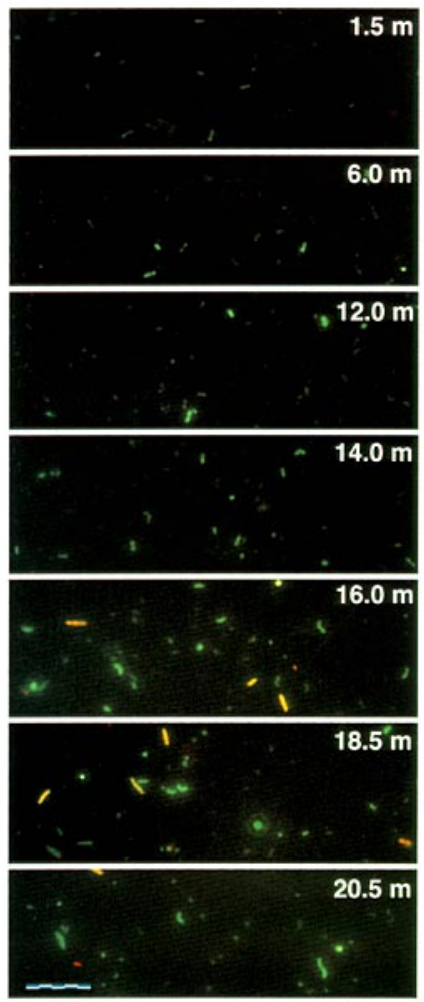